\title{
A17302 228978
}

NAT'L INST. OF STAND \& TECH R.I.C

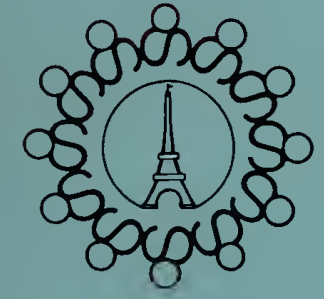

NBSIR 79-1959

February 1980

\section{Standardization in France}

US DEPARTMENT OF COMMERCE

Natıonal Bureau of Standards

Natıonal Engineerıng Laboratory

Office of Engıneering Standards

$-Q C$

100

.456

79-1959

1980 



\section{STANDARDIZATION IN FRANCE}

I. M. Martinez

Building Economics and Regulatory Technology Division Center for Building Technology

National Engineering Laboratory

National Bureau of Standards

U.S. Department of Commerce

Washington, D.C. 20234

March 1980

Prepared for:

Office of Engineering Standards

National Bureau of Standards

Washington, D.C. 20234

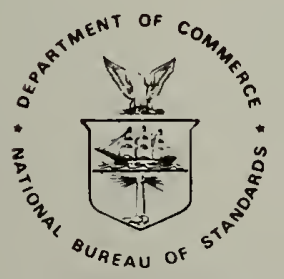

U.S. DEPARTMENT OF COMMERCE, Philip M. Klutznick, Secretary Luther H. Hodges, Jr., Deputy Secretary Jordan J. Baruch, Assistant Secretary for Science and Technology

NATIONAL BUREAU OF STANDARDS, Ernest Ambler, Director 



\section{Foreword}

In recent years, engineering standardization and product certification activities in the United States (U.S.) have received considerable attention from the Congress and others in the Federal government, and from the private sector. Increased public awareness of the significant social and economic impacts of engineering standardization and product certification has stimulated renewed interest in the workings and effects of standardssetting and certification processes, especially as these processes relate to public policy concerns such as energy and material conservation, protection of the environment, health and safety, industrial innovation and competition, international trade, and metric conversion.

As the Nation's central measurement reference laboratory, and as a major Federal scientific and engineering institution seeking to help solve national problems, the National Bureau of Standards (NBS) has played an important and well-recognized technical support role in national and international standardization activities, both governmental and nongovernmental. NBS is responsible for providing the Nation's basic measurement reference standards for the physical sciences and for the development of state-of-the-art measurement technology in these fields.

Because of this responsibility, and because of its close working relationships with product standards-setting bodies and certification agencies in the government and the private sector, NBS and its parent agency, the Department of Commerce, are frequently asked to comment on proposed national standards policy documents. Recent examples include a proposed policy governing Federal participation in and use of voluntary (non-government) standards (OMB Circular), a recommended National Standards Policy prepared by the National Standards Policy Advisory Committee, and proposed legislation ( $\mathrm{S.825}$ and HR1184, introduced in 1977) covering national and international standardization, laboratory accreditation, and product certification.

In preparing responses to these national policy proposals, questions arose as to how other countries have dealt with the kinds of issues currently facing the U.S. For example, how have other countries defined the government and private sector roles in standardization? Have other countries been able to assure adequate participation by consumer and small business interests in standards-setting? How have they handled metric conversion in standardization? To what extent do other governments support or control participation in the international standards activities of the International Organization for Standardization and the International Electrotechnical Commission? To what extent are other countries concerned with potentially anti-competitive effects of standards?

Since much of this information was not readily available in summary form suitable for study and meaningful analysis, the NBS Office of Engineering Standards initiated overview studies of the national standards systems in several highly industrialized countries. The first study was undertaken by Dr. David Hemenway, an economist specializing in industrial organiza- 
tion, a lecturer at the Harvard School of Public Health and author of the book Industrywide Voluntary Product Standards (Ballinger Press, 1975). Dr. Hemenway looked at the standards systems of Canada, the United Kingdom (U.K.), the Federal Republic of Germany, and Denmark. He provided an overview of these systems and suggested areas for possible future study of a cross-national nature.

Ileana M. Martinez, the author of this report, is a mechanical engineer who was working with the NBS Center for Building Technology at the time the report was written. She is currently with the NBS Center for Fire Research. Before joining the National Bureau of Standards in November 1977, Ms. Martinez worked for AFNOR, the official French standards organization, for seven years. As an engineer in the Building Construction and Public Works Division of AFNOR, she acquired a first hand indepth knowledge of the standards system in France.

Most of the material used in this report comes directly from Ms. Martinez's experience. For some of the chapters, very few published references are available. Of those that are available, most are not in English. Some reference works published by AFNOR in French may be consulted at the standards library at NBS. The views expressed in the report are the author's and are not necessarily those of NBS.

Lawrence D. Eicher, Director

NBS Office of Engineering Standards 
TABLE OF CONTENTS

$\underline{\text { Page }}$

FOREWORD . . . . . . . . . . . . . . . . . iii

ABSTRACT ....................... vii vi

EXECUTIVE SUMMARY . . . . . . . . . . . . . ix ix

I. INTRODUCTION . . . . . . . . . . . . . 1

II. HISTORY . . . . . . . . . . . . . . . 2

III. FORMAL ORGANIZATION . . . . . . . . . . . . 3

AFNOR ..................... . . . . . 3

Standardization Bureaus . . . . . . . . . . . 5

Commissioner for Standardization . . . . . . . . . 5

IV. THE FRENCH STANDARD . . . . . . . . . . . . . . 6

The Ratified Standard . . . . . . . . . . 6

The Registered Standard . . . . . . . . . . . 7

The Experimental Standard . . . . . . . . . . . 7

The Information Leaflet . . . . . . . . . . . . . 7

Choosing the Type of Standard . . . . . . . . . . 8

V. DEVELOPMENT OF A STANDARD . . . . . . . . . . . . . . 9

Initial Development . . . . . . . . . . . . . 9

AFNOR's Standardization Committees . . . . . . . . . . 9

Bureau Committees ... . . . . . . . . . . 11

Public Inquiry . . . . . . . . . . . . . . . 11

After Public Inquiry ................. 12

VI. MARKING AND CERTIFICATION . . . . . . . . . . . . 14

The National NF Mark .. . . . . . . . . . 14

Use of the Mark . . . . . . . . . . . . . . 14

Management of the Mark . . . . . . . . . . . 15

Testing ..................... 17

VII. GOVERNMENT REGULATIONS AND STANDARDS . . . . . . . . . 18

Regulations . . . . . . . . . . . . . 18

Government Standards . . . . . . . . . . . . 19

Antitrust Issues ............... 20 
VIII. MISCELlANEOUS . . . . . . . . . . . . . . . 22

Consumer Issues . . . . . . . . . . . . 22

The 1977 Scrivener Law . . . . . . . . . . . . 22

Labor Particlpation . . . . . . . . . . . . . . 24

Small Business................. . . . . . . . 24

IX. INTERNATIONAL AND REGIONAL STANDARDIZATION - THE

FRENCH CONTRIBUTION . . . . . . . . . . . . . 26

International Standardization . . . . . . . . 26

European Standardization . . . . . . . . . . 29

Future AFNOR Participation . . . . . . . . . . 31

Appendix 1 - English and French Terms . . . . . . . . . . 32

Appendix 2 - Building Standards . . . . . . . . . . . . 34

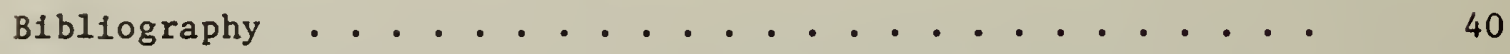

AFNOR Comments ......................... 41

Figure 1 - Standardization Law of 1941 . . . . . . . . . . 42

Figure 2 - List of Standardization Bureaus . . . . . . . . . 43

Figure 3 - List of Technical Areas covered by French Standards ................ . . . . 4 44

Figure 4 - Typical Cover Page of a French Standard . . . . . 45

Figure 5 - Standards Development . . . . . . . . . . . 46

Figure 6 - Excerpts from the May 1978 Monthly Bulletin on French Standardization (BMNF) ......... 47

Figure 7 - NF Marking Symbols ................ . 49

Figure 8 - Reprint from the officlal Dally Journal making a Standard Compulsory (published in a BMNF) . . . . 50

About OSIAD . . . . . . . . . . . . . . . . . . . 54 


\section{ABSTRACT}

This report provides an overview of the voluntary standards system of France. The author, a former employee of AFNOR - the official French standardization organization, calls on her firsthand experience to discuss the following aspects of the French standard system: (1) Organization, (2) French Standards, (3) Standards Development, (4) Certification, (5) Government Use of Standards, (6) The role of Consumers and Labor in Standardization, and (7) France's Participation in International Standards Activities.

Key words: AFNOR; antitrust; certification; product; France; French standards system; government policy; standards systems. 


\section{$\underline{\text { Organization }}$}

The French standards system in its current form was set up under a 1941 law which recognized the Association Française de Normalisation (AFNOR) as the official French standards organization. Although it is a private association, AFNOR is under the authority of a government official, the Commissioner for Standardization, and a substantial portion of its budget (which was about 15 million U.S. dollars in 1978) comes from the government.

AFNOR is governed by a Board and a General Director. Standards work in many areas is carried out by AFNOR's Standardization Committees. In addition, separate Standardization Bureaus are responsible for the standards work in a number of other areas.

\section{French Standards}

AFNOR is the only organization in France with authority to publish national standards. There were about 10,465 AFNOR standards in 1978 . The four types of standards documents published by AFNOR are: ratified standards (binding for public contracting); registered standards; experimental standards; and information leaflets (e.g., guidelines on how to interpret standards).

\section{$\underline{\text { Standards Development }}$}

In some ways, the process of developing standards in France is similar to processes in other European countries; for example, there are no formal voting or balance requirements. Standards are submitted to a widely publicized period of public inquiry by AFNOR, which is responsible for validity of consensus. For ratified standards, there is a further period of inquiry among government ministries.

\section{Certification}

AFNOR operates a certification program, using the "NF" (Normes Françaises) mark, but does not have its own testing facilities. The NF mark can only be used on products for which compliance with ratified standards covering all important characteristics of a product has been independently verified.

Generally certification of conformity to French standards is optional, but in some cases, it is mandatory, such as for gas appliances which are subject to regulation. The NF mark, however, remains optional in all cases. Elghty percent of AFNOR's certification activities relate to domestic equipment or building products. Use of the mark is managed by AFNOR special committees which decide when to grant or withdraw the privilege of using the mark. Information resulting from use of the NF mark is valuable in deciding whether to modify the standards underlying certification. 
Government Use

AFNOR's ratified standards are extensively used in French government regulations. If a suitable standard is not available, regulators may ask AFNOR to develop one. Also, standard-like documents are prepared by the government for its own procurement needs. The 1941 law provided for creation of a position in each ministry and agency to be responsible for standardization matters and to represent the government in AFNOR committees. Since 1975, renewed efforts to harmonize government "standards" with AFNOR's have met with limited success.

Consumers and Labor

There has been a consumer movement in France, as in other countries, and AFNOR has been strengthening its relationships with consumer groups. Consumer legislation passed in 1977 (the Scrivener Law) will significantly affect AFNOR's certification program. On the other hand, while many standards committee participants belong to labor unions, the unions themselves do not appear to be involved in standardization.

\section{International}

AFNOR represents France in non-treaty, non-governmental, international and regional standards organizations, namely, the International Organization for Standardization (ISO) and the European Committee for Standardization (CEN). (French participation in other international, governmental groups is through the government Commissioner for Standardization.) A large portion of AFNOR's budget goes to its international activities, and in recent years, there has been a trend toward adopting ISO standards as French standards. AFNOR is extremely active in international standards work, holding 20 percent of technical secretariats in ISO (more than the UK, Germany, or the U.S.) and 37 percent of CEN secretariats. 



\section{INTRODUCTION}

There are some basic differences between France and the United States with regard to government structure and economic organization which have implications for standardization.

First, France is divided into ninety-five geographical units called departments (plus several territories overseas) with weak local governments. The national government, centralized in Paris, has a power and influence unsurpassed by anything comparable in the United States.

Second, while the French economy is basically capitalistic and while free enterprise has an important role in the national scene, government intervention in all sectors is very common. Many services are nationalized-electricity, communications (telephone), rail transportation--and government regulates industry and commerce to a much greater degree than in the United States.

Standardization in France is viewed as a tool for implementing national policies such as increasing the competitiveness of French products in international markets, promoting international trade by reducing technical barriers, implementing national and European (Common Market) regulations, contributing to the better use of raw materials and energy, and informing and protecting consumers.

In addition, standardization is considered a public service, and this often results in very close cooperation among industry, users, consumers, government, and other institutions, with respect to standardization activities.

The standards system as it works today is well accepted; hardly anybody questions its structure or advocates any change. In the author's opinion, this is significant in light of the political and social turmoil in France today. 


\section{II. $\quad$ HISTORY}

Standardization efforts began in France during the turmoil of the French Revolution when the variety of weights and measures was enormous and the resulting confusion was considerable. In 1795 , it was for the first time politically feasible to declare legal the newly created metric system. During the second half of the 19 th century, some products were standardized in the iron and steel industry. However, in France, as in several other countries, the principal impulse toward standardization came with World War I. Between 1916 and 1918, standards groups simultaneously started getting organized in several countries.

A French legislative decree on June 10, 1918 instituted the Permanent Commission for Standardization*, a purely governmental body. This group faced many problems and was not well accepted by industry; it was dissolved for lack of funds in 1924 .

Between 1926 and 1928, there were efforts to organize standardization as a purely private activity. Among these efforts was the creation in 1926 of the Association Françalse de Normalisation (AFNOR).

Between 1928 and 1941 , several standards structures and organizations were 1 mplemented by various legislative decrees and ordinances. In order to avoid the drawbacks of an all-private or all-government approach, there was a tendency to combine the two.

Finally, in 1941, a public law determined and accurately defined the structure of the French standards system. (See Figure 1). This law emphasized the national and officlal character of standards activity and its principal actor, AFNOR, while recognizing this association as an independent institution where producers, users and government representatives harmonize their points of view in a strictly neutral atmosphere.

The law of May 24, 1941** defines the roles of three entities which are separate but functionally interdependent:

- AFNOR

- Standardization Bureaus

- Commissioner for Standardization

The framework within which these organizations function today is similar to the framework as first concelved.

* This 1 s the author's translation of the French term. English translations are used throughout this text. The French terms are provided in Append1x 1 .

** Historical note: France was invaded 1n May 1940. In June 1940, Pétain formed a government in Vichy. This government legally held all constitutional powers, including legislative authority, unt11 1944. 
III. FORMAL ORGANIZATION

AFNOR

Functions. Since its origin in 1926, AFNOR has had the status of a private, non-profit association. In addition, a 1943 decree declared AFNOR of "public interest"; this is an official recognition that goes beyond the acknowledgement of non-profit status and is formally accorded to organizations whose aims are to operate for the public's benefit.

AFNOR's functions are:

- To centralize and coordinate all standards activities in France (which are, however, under the authority and control of the Commissioner for Standardization).

- To act as the intermediary between all standardization organizations and activities and the government.

- To forward the government (Commissioner's) directives to the Standardization Bureaus and to validate and control the Bureaus' draft standards by submitting them to a period of public inquiry.

- To set up technical committees to develop draft standards when no appropriate Standardization Bureau exists.

- To publish all French national standards.

- To engage in certification and marking activities.

- To carry out public information activities, public relations programs and training related to standardization.

- To represent France in non-treaty, non-governmental, international and regional standards organizations (ISO, CEN).

Organization. Oversight for AFNOR's activities is the responsibility of the Commissioner for Standardization, a government official. Economic and financial oversight is provided by a controller/auditor appointed by the Ministry of Economy and Finances. (A substantial portion of AFNOR's funding comes from the government.)

As a private association, AFNOR is administered by a board of directors composed of an honorary chairman, a chairman, 2 vice-presidents, and some 25 to 30 members. For the day-to-day activities, the Board elects a general director who in turn chooses AFNOR staff. Some 380 people were employed by AFNOR in 1977.

The Board of Directors meets three times per year. It is not involved in any standards-specific decisions nor concerned with the mechanics of the development, decision to publish, or conditions of application of particu- 
lar standards since these procedures are well defined by official, published decisions. Rather, the Board's responsibilities lie mainly in giving overall guidance, establishing policy in close coordination with the Commissioner and the Bureaus, managing the finances of AFNOR, establishing the fees paid by the members of the association and setting the price of standards and other services provided by AFNOR.

AFNOR's General Assembly, which includes all AFNOR members, meets once a year to approve the financial and status reports presented by the Board of Directors. Membership in the association is open to all who are accepted by the Board of Directors and pay an annual fee. Participation in standards work and contribution to standards development and committee work are not reserved exclusively for association members. However, most committee members are association members.

AFNOR maintains six small (one staff person) field offices in Bordeaux, Lille, Lyon, Marseille, Nancy and Rennes.

AFNOR has standardization committees in many areas such as toys; refrigeration; fire-fighting equipment; paints; documentation; chemistry; leather and skins (hide); acoustics; statistics and sampling theory; safety equipment such as safety shoes, helmets, protective clothing, stretchers, etc.; gymnastic and recreational equipment; camping; fruits and vegetables; units and symbols (in general); science of terminology; colors; pictograms; ergonomics; and commercial relations (supplier and user).

These committees are responsible for developing standards. Chapter V gives a detailed explanation of how these committees work, how they are managed and who runs them.

Budget. AFNOR's budget for 1977 was 58,690,000 French francs (about 13 million U.S. dollars). By 1978, it was 70,718,000 French francs (about 15 million U.S. dollars). Until 1975, AFNOR's budget was about equally divided between a government subsidy and its own resources (sales of standards and other pubilications, membership fees, conference room rentals to outside firms, etc.)

The government subsidy was collected as a very small percentage of a fiscal tax imposed on all industry, business and commercial enterprises.

A fiscal reform in 1975 abolished this tax, and AFNOR's budget was seriously threatened. Since then, the government has continued to help support AFNOR on a year-to-year basis to avold a financial crisis. In the meantime, AFNOR's Board of Directors has been attempting to develop other sources of support, mainly from industry and business. Membership fees have been increased to reflect the size and importance

AFNOR currently receives an annual subsidy from the Ministry of Industry which represents about $40 \%$ of its budget. 
of the member. Successful agreements with certain groups for specific projects have been concluded, but as yet no financial structures have been set up to guarantee AFNOR's future financial stability.

\section{Standardization Bureaus}

Standardization Bureaus are independent organizations, structurally separate from AFNOR and from the Commissioner for Standardization. They have been described as the "technical agents for the development of standards". Their legal status varies widely because these bureaus are associated with very diverse organizations, such as professional organizations, trade groups, users' associations, and research and development organizations. In each case, however, their function as Standardization Bureau has been established by government decree. Also, they all have in common the public service nature of their work which primarily consists of the initial preparation and development of draft standards. Standardization Bureaus cover many areas including: aircraft and space vehicles; agriculture; rubber; automobiles; railroads; cinematography; ship-building and navigation; electricity; bottling; foundry (cast iron); gas; clothing; watch and clock making (horology); computer sciences; plastics; mechanics, metals; paper; photography; steel industries; welding; and textiles. (See Figure 2 for a complete list of Standardization Bureaus.) For these areas, standards are developed by committees under the leadership of the Standardization Bureaus. (See also Chapter V.)

\section{Commissioner for Standardization}

The Commissioner for Standardization is a civil servant appointed by the Ministry of Industry, but serving in a liaison capacity with other ministries, in particular, the Ministry of the Interior.

\section{His functions are:}

- To establish general directives for the standards organizations.

- To verify compliance with standards developing procedures.

- To define the status of each standard and its implementation (conditions of application).

- To arbitrate differences between standards organizations.

- To establish and carry out a standards program.

- In the international field, to assure that AFNOR performs its specific mission and to undertake standards related activities that are the government's responsibility (participation in treaty and/or governmental organizations such as the Commission of European Communities in Brussels, the United Nations Economic Commission for Europe in Geneva, and the General Agreement on Tariffs and Trade). 
AFNOR is the only organization in France with the authority to publish national standards. Its authority rests upon statutes related to the promulgation and use of French Standards and the public confidence which AFNOR enjoys.

In 1976, there were about 7,600 French national standards. By 1977 , about 9,900 French national standards in a large number of technical areas had been published. In 1978, the total number of standards had risen to 10,465 , of which 873 were published during that year. Figure 3 lists 21 of the broad categories of technical subjects covered by French standards, as they appear in AFNOR's annual Catalog of Standards.

Traditionally, there was only one type of standard published. A variety of reasons, among which reducing the time needed to develop a standard was particularly important, led AFNOR in 1966 to develop a system to differentiate between standards. This system was approved by the Commissioner for Standardization in his "Decision no. 9 relative to the nature of official documents of French standardization" (July 11, 1966).

This decision gives AFNOR the authority to publish the following four types of standards documents:

- the ratified standard

- the registered standard

- the experimental standard

- the information leaflet.

The printed copy of a French standard clearly states in the upper left hand corner the type of standard it is (see Figure 4).

The Ratified Standard

This is the oldest and most widely accepted type of standard. Its publication and conditions of application are proposed by AFNOR (and the standardization committee) and are approved by the Commissioner for Standardization. Before giving his approval, he undertakes an extensive (four weeks) period of inquiry directed to all the ministries and ministerial offices interested in the subject area. If there is no opposition to the particular standard, it is ratified, and this ratification becomes official through publication in the official Dally Journal (similar to the U.S. Federal Register).

The law of 1941 states that ratified standards are to be used for all contracting by the State and where any government funds are used, whether or not these standards are explicitly referenced. In the private sector, the contracting parties are free to do as they wish. They may or may not 
refer to national standards, but if they do, they are bound in the eyes of the law to comply with the standard provisions. However, in cases of litigation if the contractual documents lack other reference, French AFNOR standards are usually cited in civil courts as representing the state of the art. Only when a standard is incorporated (by reference or explicitly) in a regulation does it become compulsory in the broadest sense.

All the administrative paperwork for ratifying a standard is carried out by AFNOR, in part because the Commissioner has a very small staff (two or three usually) and in part because of AFNOR's comprehensive knowledge of the development process and technical content of the standard.

\section{The Registered Standard}

The development of this standard involves slightly simpler procedures at the final stages of the development process. A simple decision of the Commissioner of Standardization without any further inquiry approves a proposal presented by AFNOR. In 1971, a government circular recominended that public contracting refer in a systematic way to registered standards, a treatment similar to that previously reserved for ratified standards.

\section{The Experimental Standard}

By a decision of AFNOR's General Director, a draft standard may be published as "experimental" without being previously submitted to any kind of public inquiry. This may be appropriate for a variety of reasons. For example, there might be a need to conduct further research, while at the same time it may be desirable to reach a wider audience than the standardization committee and for longer periods of time in order to reach valid consensus.

Experimental standards are included in the catalog of published French standards and, like other standards, they are available for consultation, use and purchase. Generally, an experimental standard is reviewed within a maximum of three years and is revised before submitting it to the usual procedures prior to publication.

As intended, this method of developing standards has been used in relatively few cases. The usefulness and success of these documents in recent years has led to their increasing popularity.

\section{The Information Leaflet}

There is a broad category of information quite valid and useful to the general public, industry, users, consumers, etc., but not suitable for a standard. If proposed by an appropriate standardization committee and approved by AFNOR's General Director, such material may be published by AFNOR in information leaflets. 
These information leaflets might include guidelines on how to implement performance standards (a how-to manual), such as guidelines describing construction details of windows and doors that comply with the performance specifications of the ratified standard. Also, some complex standards often may require interpretation. AFNOR receives many such requests to clarify meaning, and when they are repetitive in nature, the formal publication by AFNOR of the committee's interpretation becomes very useful to the user of the standard. Such was the case recently for the interpretation of safety rules for the construction and installation of elevators.

\section{Choosing the Type of Standard}

All the preliminary work of examining and modifying a draft is done by the appropriate standardization committee, either an AFNOR committee or a Standardization Bureau committee. Which type of standard will be proposed for publication is entirely the committee's decision.

Tradition intervenes to a large degree when choosing between the ratified and the registered standard. For example, in the steel industry, all standards are registered, while the building community prefers ratified standards.

However, there are often important reasons for choosing one type over the other. The decision may depend on the make-up of the industry, since ratified standards are compulsory where any public funds are used, while registered standards are not.

The nature of experimental standards and information leaflets is such that the technical content of the documents usually determines which type of document is suitable. The decision again is entirely left up to the committee. The General Director of AFNOR has the authority to approve publication of these two types of documents, and his approval is needed each time a document is proposed by a committee. AFNOR's General Director acts only on proposals presented by a committee, and he rarely questions the committee's wisdom.

Many committee members are not very familiar with the subtle differences between types of standards, and AFNOR staff thus can and often do exerclse considerable influence in guiding the choice. However, AFNOR seldom acts without the advice and consent of its committee. 
Standards are developed in France in much the same way as is customary in the United States (see Figure 5). There are some important differences in the development of a standard by an AFNOR committee as opposed to development of a standard by a Bureau, but since the most important stages are the same, they are treated together in this paper. When necessary, the differences will be pointed out.

The subjects covered by standardization go from the very exotic to the highly technical and scientific to the most common everyday products. Figure 6 shows some of the areas where standardization work was ongoing in May 1978.

\section{Initial Development}

The request to develop a standard in an area where there is no Bureau may be received by AFNOR from a variety of sources: a consumer association, a manufacturer, a user, a testing laboratory, a special interest group, a government agency, etc. Occasionally, AFNOR will perceive the need for a standard in the public interest and may initiate appropriate action.

The request is accepted on the basis of its merit, if there is sufficient broad interest to nurture a committee's work. Usually, to support its request, the petitioner presents an initial draft or proposes a competent individual to prepare such a draft.

For a standard developed by a Bureau, the initial stages of work are carried out at the Bureau's own initiative with the knowledge of AFNOR but without any supervision.

AFNOR prepares an annual plan which lists standards to be developed or areas where work will be carried out, including the year in which standards identified in the plan are expected to be published. Short and long range plans are included.

\section{AFNOR Standardization Committees}

Standardization committees (technical committees) are the heart of all AFNOR standardization activity; they are where the important decisions are made. In 1977, AFNOR had 972 standardization committees with a total membership of over 34,000 experts.

A committee chairman is elected in an informal way at a first organizational meeting and is usually a person of significant prestige. He or she may come from industry or a user's group, or some other group. Occasionally, an individual expert is chosen. An AFNOR technical staff member, representing strict neutrality among interests, may be selected to chair a committee. The secretary of the committee is always an AFNOR technical staff member. 
The duties of the chairman and the secretary are relatively well defined, even though as might be expected there is room for diversity. The chairman is not expected to handle any of the paperwork of a committee. Notice of meetings, documents to be studied, redrafts, and minutes of meetings are all prepared and distributed by AFNOR. Decisions are recorded by the secretary. The chairman leads the technical discussion and acts as the catalyst to reach appropriate compromises, turning to the secretary for all procedural questions.

Meetings are held almost invariably at AFNOR's headquarters building. $A F N O R$ has the staff and physical facilities to ensure efficiently run meetings. In 1977, AFNOR hosted some 2300 meetings; 70 percent of those meetings dealt with national standards, and 30 percent with international work, including international meetings and preparation for those meetings.

This method of work has proven quite effective in developing national standards because of the simple principle of division of labor: each member has a defined task to perform, and the sequential steps are predetermined.

There is no formal membership in AFNOR's committees. An initial membership list is drawn up by AFNOR staff, based on their own experience and input from other sources, in an effort to achieve the widest representation possible. This list is read at the first organizational meeting, and further nominations are made. There is an effort to recruit individuals who represent their organization -- wherever possible a trade association or other group --but no one is barred from participation. The philosophy is that if anybody is interested enough to participate, he or she should be allowed to do so.

There are no set rules for achieving balance within a committee. However, balance is a strong concern and it is very much in the minds of all participants. While no written guidelines have been adopted, great efforts are expended in striving for balance, and this is one of the main responsibilities of the secretary (AFNOR) of the committee.

Information concerning the creation of new committees and the highlights of the on-going work of all committees are reported monthly in an AFNOR bulletin, the Bulletin Mensuel de la Normalisation Française (BMNF). Two typical pages of a BMNF are shown as Figure 6 . Usual entries give a short summary of the agenda of every national and international (ISO, CEN) meeting held at AFNOR or elsewhere in France, as well as international meetings held outside of France. Activities related to certification and marking are also included. This allows an interested party to keep track of regular committee activities. AFNOR may be contacted for further information on committee work, including the possibility of becoming a member of a committee.

AFNOR, as a private association, has members who pay yearly dues and recelve in exchange AFNOR's regular publications (such as the BMNF, the Journal of Standardization, the annual catalog), some special services, 
and discounts when ordering standards. Most members of standardization committees are also members of AFNOR. However, association membership is purely voluntary and the technical staff of AFNOR who manage the committees do not check each individual's membership in AFNOR. Participation in committee work is encouraged, not restricted.

Usually, a first draft prepared by the petitioner is available at the first organizational meeting. If this is not feasible, AFNOR staff may develop a first proposal.

The committee meets as often as it wishes, and it continues to meet until it agrees upon a text that is suitable for wide distribution, either for public comment and subsequent issuing as a ratified or registered standard, or for consideration as an experimental standard or information leaflet.

There is no formal voting in AFNOR's standardization committees. In lieu of voting, agreements are reached on the basis of consensus of all interested parties and this consensus is manifested by tacit approval, i.e., when no objections are voiced. Compromise is an integral part of this process.

\section{Bureau Committees}

When a standard is developed by a Bureau, a committee similar to an AFNOR committee is usually formed. They are, however, not called "Standardization Committees". Representation in these committees is decided by the appropriate Bureau and it is usually quite broad, though this varies from Bureau to Bureau. It is in the best interest of the Bureau to provide for wide representation in the early stages of a standard's development, as this will speed up agreement during the public inquiry which AFNOR later undertakes to validate consensus before publication. Unfortunately, in many instances, a lack of sufficiently broad input during the early development of a standard leads to substantial modifications of the draft, to take account of responses to AFNOR's public inquiry. This considerably delays the issuing of the standard. All draft standards developed and approved by a Bureau must be transmitted to AFNOR which then processes the documents until publication.

\section{Public Inquiry}

AFNOR is responsible for establishing the validity of consensus of all standards, and the handling of the public inquiry is crucial to the consensus process. All draft standards, however developed, are submitted by AFNOR to a period of public inquiry lasting three months.

The public inquiry is widely publicized in AFNOR's monthly bulletin (BMNF) and in press releases in appropriate technical and trade publications. AFNOR encourages the technical and trade press to circulate standardsrelated information and to reprint its news releases as widely as possible. 
All comments formulated during the public inquiry are received and sorted out by AFNOR. A meeting of the standardization committee is called to examine and resolve negative comments, as well as suggestions for improvements. Since there is no formal voting, a committee's honest attempt to accept most comments and modify the draft standard to reflect expressed opinions are vital. It is AFNOR's responsibility to make sure all interested parties have been contacted, and all comments have been thoroughly examined. Comments must be resolved to the satisfaction of the committee members and AFNOR's staff representative. Parties who offered comments and/or volced objections during public inquiry are expressly asked to attend the meeting(s) where their comments will be discussed (whether or not they are members of the committee). Depending on the outcome of the meeting(s), the committee makes the decision to approve the draft, and it proposes the type of standard it prefers, ratified or registered.

If a draft receives comments such that the committee cannot approve it, two possibilities are open. The draft and comments may be sent back to the standardization committee for consideration, or alternatively, the committee may redraft a standard. If it has been substantially modified, the new draft must be submitted again to public inquiry.

The statutes defining the registered standard allow AFNOR in some cases to forego the public inquiry. AFNOR has used this authority to permit some standards to be published without the formal review period.

Neither an experimental standard nor an information leaflet require a public inquiry for publication, but in some cases a public inquiry may have taken place. For example, at times a draft thought suitable by the committee may be proved by a public inquiry to be too "experimental" for publication as a ratified or registered standard. Alternatively, the committee may decide to issue an experimental standard without any outside comment. An information leaflet is seldom submitted to a formal public inquiry, but it is often informally submitted for comments to a broad audience before publication.

After Public Inquiry

After a draft has been modified in response to comments received during public inquiry and approved by the committee, AFNOR prepares all the administrative forms for processing the standard and submitting it to the Commissioner for ratification or registration.

In the case of ratification, AFNOR, acting in the name of the Commissioner, handles the ministerial inquiry. In the case of registration, no further procedures are required besides obtaining the Commissioner's approval.

Before publication, no other group within AFNOR further reviews the standard's technical content. However, uniformity in presentation and format, correct use of units and symbols and a certain degree of homogeneity 
are assured by a general-services group within AFNOR which suggests adjustments when necessary. The publication and printing of standards, as individual pamphlets, are handled by AFNOR. 
In France, compliance to a national standard may be shown in several ways. For example, a manufacturer may claim in his literature that his product conforms to a particular nationally recognized AFNOR standard, or the product 1 tself may even carry an explicit claim of conformity. However, unless they are covered by the national certification program, products may not be marked with any sign resembling the NF symbol or any other character which misleads the consumer into thinking that the product is recognized by the national certification program.

The preferred way to show conformity to a national French standard is to have an independent, reputable organization back up the manufacturer's claim. This system is institutionalized in a national certification program, which is symbolized by the national NF mark.

\section{The National NF Mark}

The national mark NF (for "Normes Françaises") was instituted in 1938. The 1941 law relating to standardization also determined the present organizational framework that governs the French certification system and sanctioned AFNOR as the only body in France officially recognized to run the NF mark, the officially recognized national certification program.

The NF mark is meant to indicate a product's conformity to one or more ratified, national AFNOR standards. Therefore, only ratified standards that cover all important characteristics of a product showing its appropriateness for the intended use may serve as a basis for certification. For example, a mark could not be issued for a certain product solely on the basis of the product's compliance with a dimensional standard.

The NF symbol affixed to a product means that:

- the product is in conformity with a standard(s)

- this conformity is verified by independent testing organizations at production and randomly before and after marketing

- In case of non-conformity, the responsibilities for correcting the problems are clearly defined.

F1gure 7 shows the principal NF marking symbols.

Use of the Mark

Use of the NF mark is optional in all cases. It may only be used under license. Usually, a marking program is initiated when a sufficiently large proportion of French producers of a specific product expresses an interest in such a program, and the suitable standards exist. Once a program is established and a majority of producers use the mark, competitive forces usually cause most of the remaining producers to also participate. 
A standard can be made compulsory by incorporating it into regulation by reference. Comformity to that standard may also be made mandatory by special government decree. In such cases, the mark is a very convenient way to show that a product conforms to the standard. However, the use of the NF itself is never mandatory.

In France, all gas and many electric household appliances are subject to regulations. These regulations reference AFNOR standards, and the NF mark is very extensively used to certify that these appliances actually conform to the required standards. Another important area where the NF mark is widely applied is firefighting equipment.

The NF mark is used in some 70 areas. Domestic equipment comprises about 40 percent of AFNOR's marking and certification activities. Building materials and components make up another 40 percent while the rest relates to other industrial products. The total number of products carrying the NF mark totaled, at the end of 1978, about 17,500 models from 1,650 licensees.

Granting the NF mark to foreign products is authorized, provided the products satisfy all of the requirements established for national products, that effective policing of compliance is possible, and that reciprocity exists. Some foreign products have been approved to use the mark, most notably in areas where the standards are mandatory. Thus the mark is quite useful for marketing the product in France.

Management of the Mark

The management of the NF mark is carried out by the Directing Committee under the overall authority of the Commissioner for Standardization who appoints members to this committee from a list of nominees proposed by AFNOR's General Director. The role of the Directing Committee is to oversee and coordinate the work.

Day-to-day activities are carried out in a decentralized fashion through special committees. Each special committee is set up in close liaison with professional groups, users and interested administrative agencies. Each special committee writes its own by-laws. These by-laws, however, follow a regular pattern and are thus not very different from committee to committee except for obvious reasons, specific to each product. The special committees process the requests from producers for authorization to use the mark, arrange for the controls, and propose the sanctions, if any, to be applied to delinquent products. For many of the marks, quality control is two-fold: random samplings of products both at production lines and in the market by independent controllers are coupled with inhouse, dafly quality control. Different industries have different capabilities for performing such internal checks, so the rules of the mark are adapted accordingly. The intent is to increasingly orient companies to be able to verify their own production and to diminish the importance of outside spot-checks.

Special committee by-laws usually provide for inspection visits to factories to insure the adequacy of the equipment avallable. Special committees 
may also supplement the standard if needed in areas frequently overlooked by standards-writers, such as the frequency of sampling, size of samples, how to take into account dispersed test results, etc.

There may be one special committee per class of products or alternatively the special committee may cover a vast sector, making it necessary to further subdivide the special committee into stamping committees. For example, the Taps and Faucets (Valves) Special Committee has four stamping committees (sanitary/domestic, industrial, gas, and heating), while the concrete roof tiles committee has no subgroups.

Membership in the special committees is strictly regimented in marked contrast to membership in AFNOR's standards-writing committees. Balance rules are formal and strictly enforced. Membership is on a personal basis, and individuals are representatives of a given interest. Alternate members are accepted only under extraordinary circumstances. The composition of each committee changes every two or three years.

In general terms, the composition of the special committees is one-third producers, one-third users, and one-third administrative agencies comprising not only governmental groups but also nationalized institutions such as the railroads, Electricite de France, and others. The head of the technical section in AFNOR, responsible for the development of the standard, is a committee member. Representatives of testing labs also participate actively in committee work but are not voting members. The chairman of a special committee is selected from among the users by all committee members; the secretary is always an AFNOR staff member.

Decisions to grant or revoke the privilege of using an NF mark are made only during committee meetings by consensus on the basis of test results and other related reports. Testing organizations themselves make no decision as to product conformity, they merely report test results to the special committee. Special committee by-laws provide rules for voting, but often there is no need for formal voting, because members are used to the style of standardization committees where amiable agreement is common. However, the proceedings of certification committees are much more formal than their counterpart standardization committees.

When first starting, committees meet quite often in order to develop and approve the by-laws. In addition, these initial meetings of ten deal with issues such as sampling, size and frequency of test-piece selection, acceptability levels, etc. This is necessary because some standards used for certification purposes lack clarity in these areas, and while a standard may be quite acceptable without these types of statements, an NF certification program cannot function without them. After the initial organizational period, the committee meets twice a year to examine test results, assess any emerging problems, evaluate and issue warnings if necessary, and, eventually, apply sanctions. A first offense is usually admonished by a letter of caution, and repeated offenses carry increasingly stronger action including removal of the privilege of using the ma rk. 
The entire certification program is of great importance to standardization. Often in a first generation standard, levels of performance are fixed after considering only a limited size population. In the day-today application of standards, the level of performance actually attained by a product may be more accurately appraised. This accumulated knowledge may lead to a proposed modification of a standard. Sometimes the change relaxes the provisions of the standard. More often than not, a product performs consistently better than originally estimated, and the standard is upgraded.

When this happens, a special committee may request AFNOR and the appropriate standardization committee to revise a standard, giving all needed technical justification for the proposed modification.

The recent law concerning consumer protection and information ${ }^{*}$ will affect the use of the NF mark on consumer products. The NF mark program already implements many of the provisions of the law, but some changes may be forthcoming. In particular, the mark may have to be more informative, especially when used for consumer products.

\section{Testing}

AFNOR, which has the management responsibility for all NF marks and certification committees, has no laboratories or test facilities.

A testing house is selected to perform the tests for each individual mark created. Most often there is only one candidate with the qualifications required to carry out the work. When more than one laboratory is necessary, an equitable distribution of testing activity is made. The decision is AFNOR's, and it is reached after extensive consultation with interested parties. In 1977, AFNOR reported that 23 official laboratories were charged with carrying out tests for the NF mark. There is no program in operation for accrediting testing institutions, so no formal criteria have been developed for selecting testing houses to take part in AFNOR's certification programs. 
VII.

$\underline{\text { Regulations }}$

AFNOR's ratified standards are extensively used in French government regulations. This is accomplished in a variety of ways.

The most frequent type of use is direct reference to a standard. Direct reference is being increasingly used in Europe, and it is strongly advocated by such intergovernmental bodies as the United Nations' Economic Commission for Europe and the Commission of European Communities. Typically, the government in France regulates through direct reference to a standard when the application of such regulation is non-discriminatory,

applicable to all concerned. The regulation is issued through a statement published in the official Daily Journal that a particular standard is mandatory. This information is widely reprinted in AFNOR's periodical publications and the technical press. (For an example of this kind of information printed by AFNOR, see Figure 8.) Usually, the standard itself, as sold by AFNOR, clearly states its legal status. As of January 1978, some 200 standards in 25 sectors were incorporated in regulations by direct reference.

Government regulations incorporate AFNOR's standards in other ways, for example:

1. Regulations may reproduce in full the text of French standards, and may or may not mention the original source.

2. Regulations may be based on a standard or part thereof, but may not expressly mention the AFNOR source document.

3. Regulations may require conformance to a particular standard by a specially designated group only. Typical of this category are certain AFNOR testing standards that have been made mandatory for use by government, by officially accredited labs, or for settling disputes, particularly for agricultural and food products.

When the need arises, regulatory authorities either use an existing standard, if a suitable one is available, or they ask AFNOR to develop one. In the former case, the degree of urgency and the purpose of the regulation are often made clear to the corresponding standards committee so that 1 ts members may take advantage of the guidance and have a better chance of producing a standard suitable for regulatory purposes. This is usually done in the formal letter of request and/or accompanying documents. Also, AFNCR staff usually confer extensively with regulatory officials before committee work starts.

Regulatory officials may take part in committee work, but generally they do not. If they choose to take part in the development of a standard, their participation is governed by the usual AFNOR rules: they may particlpate if they so wish, and the role they play may range from active 
(e.g., serving as committee chairman) to passive (e.g., a committee observer). A regulator's actual interest in committee work varies widely depending on technical knowledge, purpose of regulation, available time, etc.

\section{Government Standards}

The public sector in France develops many technical documents for its own procurement needs. Even though they are not called standards and make no claim to this effect, they are, for all practical purposes, standards. The use of the term "norme" (meaning "standard") in France is mostly limited to nationally recognized standards. In part this is possible because there are a plethora of other terms such as "cahier de charges," "cahier de prescriptions," "cahier de clauses administratives/techniques," and "recueil de décisions". Even the English word "standard" may be used to refer to technical documents which may be construed to be standards. It is rare in France to refer to "French government standards".

There are several groups in different government agencies* that develop such documents. The most important one is the Central Commission for Markets (CCM) and their Permanent Groups for the Study of Markets (GPEM). They are within the authority and administrative structure of the Ministry of Economy and Finances, but their standards are applicable to all ministries and public groups.

In addition, many ministries have internal committees that draft standards (e.g. the Ministry of Education) for their own procurement needs. There is a close liaison between the CCM and AFNOR at the highest level of authority. The Secretary General of the CCM is a member of AFNOR's Board of Directors, and some coordination is attempted relative to longrange planning in areas of common interest.

AFNOR's technical staff is invited to participate in the work of these government groups, but they seldom do so. In the last few years, selected GPEM documents that may be applicable to the private as well as public sector, have been referenced in AFNOR's annual catalog, which lists all standards.

The Standardization Law of 1941 provided for the appointment, within each ministry and agency, of an official who would be responsible for all standardization matters and who would be the Commissioner's correspondent. In 1975 the duties of this official were redefined as follows:

- To contribute to standardization work and represent the appropriate government ministry or agency in AFNOR's committees.

* It is useful to keep in mind here that France is not, like the U.S., a federation of independent sovereign states, but a highly centralized republic. 
- To make sure the period of inquiry within the ministry or agency is used effectively.

- To encourage implementation by the government of AFNOR's ratified standards where applicable.

- To participate in the development of the government's and AFNOR's annual standardization program (these programs typically list and prioritize standards to be developed, with short-range and longrange goals).

- To transmit to the Commissioner any request for non-implementation of a particular standard (this is rare, as may be expected, because it is not possible to ratify an AFNOR standard over the objection of any ministry or agency).

- To be the liaison between the ministry and the CCM and to carry out functions analogous to those carried out with respect to AFNOR concerning representation, period of comments, etc.

- To be the focal point for coordination and exchange of information relative to standardization within the ministry.

- To contribute to the coherence of the government's standardization policy, including quality control and certification.

The duties of internal coordination and information as well as liaison with other government bodies seem to have been the most effective activities of these officials.

Concurrent with this restructuring, renewed efforts to harmonize government "standards" with AFNOR's have met with limited success. Few sectors have accepted the idea of uniformization with enthusiasm. One of the areas where progress is foreseeable in the next few years is in construction. Some modest efforts are presently underway between AFNOR and the Central Laboratory for Bridges and Roads ( $L C P C$ ) of the Ministry of Equipment (Public Works) concerning specifications for some granular materials for concrete.

\section{Antitrust Issues}

France does not have comprehensive, actively implemented antitrust legislation.

Since the end of World War II, industrial groups and trade associations have been allowed to impose minimum prices on their products, but this is no longer condoned.

Antitrust issues are of much less concern in France than in the U.S. Many trade or industry associations regularly discuss and of ten agree on their respective pricing policies. The government exercises a strong influence 
in fixing prices in some sectors and controls the price of some key commodities, such as cement.

In 1977, new rules applicable to excessive economic concentrations were adopted in France. These new provisions bring French legislation closer to Common Market cartel law. The new law establishes criteria for selecting activities subject to control. The intention is to subject some operations to scrutiny by government, not necessarily to impose sanctions on activities deemed to be in the national interest. The appropriate Ministry, on the basis of the evidence, decides on its future course of action and may issue warnings or sanctions or exempt the industry from compliance with the regulations.

It is unclear at this time how this new development will affect standardization. 


\section{MISCELLANEOUS}

\section{Consumer Issues}

In France, consumer participation in the development of standards relating to consumer products is a reaffirmation of the statutory principle of achieving agreement through wide representation in standards-developing committees. Legislation dating back to 1930, including the Standardization Law of 1941, explicitly refers to "consumers". and instructs that they be adequately notified of drafts submitted for comments during the public inquiry period.

As part of the worldwide consumer movement, consumers in France have organized into many groups. In addition several public organizations are responsible for consumer issues. One is the National Committee on Consumption (CNC), a government agency of the Ministry of Economy and Finances which acts as the principal permanent public authority on consumer issues. A second is the National Institute on Consumption (INC), also under the guidance of the Ministry of Economy and Finances but largely autonomous.

\section{The 1977 Scrivener Law}

A third government group, the "Agency for Consumer Affairs"* sponsored consumer legislation, which became law in December 1977. (This agency has since been dissolved and replaced by other groups.) Certain provisions of this law, known as the Scrivener Law, will considerably affect standardization. In particular, it will affect certification practices now followed by AFNOR's NF mark program. However, many of the provisions of this law are vague.**

The Scrivener Law which complements a 1905 law on fraud and falsification of products and services gives the Council of Ministers power to outlaw or regulate products dangerous to the safety or health of consumers. Interestingly, this law defines "consumers" as any uninformed or

* "Agency" here is a very loose translation of the French "Secrétariat d'Etat" small organizations with variable life spans. "The head of this type of independent department has ministerial ranking and serves on the Council of Ministers, headed by the Prime Minister. At one time or another in the last 5 years there have been "agencies" in charge of the penal system (in addition to the Ministry of Justice), of universities (in addition to the Ministry of Education), and others.

** "Implementation decrees" to clarify and interpret a law must be published before a French law becomes effective. Many months may pass before such decrees are approved and published in the official Daily Journal. At times, it takes years and, occasionally, implementation decrees are never published, as was the case with a 1963 law concerning industrial labeling. 
unforewarned persons. Most significantly, it stipulates that a certification may only be issued by an organization that is not under the control of the manufacturer or seller. Moreover, if a label is attached to a consumer product, it must be informative. This means that a mark or symbol by itself will no longer suffice if the product is intended to be put on the consumer market.

Precise details of labeling are not specified in the Scrivener Law, and implementation decrees will be published. Also concerned groups will coordinate their efforts and help develop acceptable labeling guidelines that will meet the law's intent.

Consequently, there may be serious implications for AFNOR certification programs and the NF mark. The NF mark program already conforms to many of the provisions of the law, but, for consumer products in particular, some of its rules will have to be modified in order to provide the user with more information.

Consumer Participation in AFNOR. In France, as in most industrialized nations, recent years have witnessed an increasing interest by many sectors in consumer affairs. Before the Scrivener Law, AFNOR had begun strengthening its relations with consumer groups. These efforts included a series of agreements between consumer groups and AFNOR encouraging consumer participation in AFNOR committees and opening new avenues of cooperation. Between 1973 and 1977:

- Representatives of CNC and INC agreed to serve on AFNOR's Board of Directors and on the NF Mark Directing Committee.

- A triangular relationship between CNC, INC and AFNOR was established to consult on issues relating to the development of consumer product standards: (a) when work on a new subject is being considered; (b) at the first organizational meeting of a new committee; (c) any time that an important issue in the standard is to be decided; and (d) during public inquiry.

- Extensive consultations regarding the establishment and adoption of annual standardization programs for consumer standards are now common practice.

- A committee on consumer affairs was created within AFNOR's Board of Directors, in parallel with ISO's Consumer Policy Committee (COPOLCO).

Operational agreements have been finalized between AFNOR and consumer groups to enable consumer representatives to participate in committee work in an appropriate capacity, that is, not necessarily to serve as technical experts, but rather to articulate the needs of product users.

Another organization that may play an important part in implementing the Scrivener Law is the French Association for Informative Labeling (AFEI). AFEI's main objectives are to establish guidelines for the uni- 
form, clear presentation of information on labels for consumer products. Since its creation in 1970, this association has closely cooperated with AFNOR. A longstanding agreement assures that whenever an AFNOR standard exists, the AFEI label references it.

\section{Labor Participation}

French labor unions are very different from unions in the U.S. They are divided along political, ideological lines rather than by craft. They are highly politicized in spite of a law that allows unions no political, religious or commercial activities. Significantly, union membership increases markedly during periods of heightened political activity.

Presently, only a few* major labor confederations are considered "representative" at the national level. While many other unions exist, in practice only these important and representative unions have certain powers.

In spite of the important role played by organized labor in France in national affairs, a smaller percentage of the French working population join unions than in the United States, Germany or the United Kingdom. The number of members in a union varies with the type of profession or industry. Highly unionized sectors include those employing printers, teachers, gas and electricity workers. In contrast, textile and retail workers are less unionized.

While many participants in standards work are members of one of the najor unions, labor unions as an institution do not contribute to the standardization process. To the author's knowledge, organized labor has not addressed the issue of standards development and has not approached AFNOR (as consumer groups have) for specific participation agreements.

Smal1 Business

Many small businesses in France are grouped into associations, which in turn group to form national federations. These associations are of ten regionally based and seldom have the resources to participate actively on standards developing committees, all the more so since all meetings are held in Paris. These groups must rely on the national federations to present their points of view to standards committees. This system functions effectively for small businesses when all the businesses in an association are small, and consequently federation headquarters are sensitive to small business interests.

Small businesses that do not belong to any association have no institutional mechanisms for voicing their opinions in standards activities. Their options are limited to reading technical publications that carry information on standards development work, or to subscribing to AFINOK as

Five for wage earners, including one for supervisory and managerial personnel, and one for employees 
request membership on an AFNOR committee, and this is usually possible if the individual or company has some vested interest in the area of work.

If the individual or company chooses* not to be a member of the committee, he or she may always contribute comments when a particular draft is submitted to public inquiry.

In the experience of the author, no one has ever been refused membership on AFNOR'S standardization committees. The situation is different for standardization bureaus committees, where membership is more restricted. 
Among AFNOR's major responsibilities, the most unique is representing France in non-treaty, non-governmental, international and regional standards organizations, namely, the International organization for Standardization (ISO) and the European Committee for Standardization (CEN). However, French representation in the International Electrotechnical Commission (IEC) and the European Electrotechnical Committee for Standardization (CENELEC) are not under the auspices of AFNOR.

French participation in other international governmental groups where standardization is discussed is conducted through the Commissioner for Standardization. Such groups include the Economic Commission for Europe of the United Nations (UN/ECE), the General Agreement on Tariffs and Trade (GATT), the Food and Agricultural Organization of the United Nations (FAO), and the Commission of European Commmunities (CEC)*. AFNOR participates quite actively in many of these activities.

\section{International Standardization}

ISO Purpose. ISO (the International Organization for Standardization) is the international, non-governmental agency for standardization. It brings together the interests of producers, users (including consumers), governments and the scientific community in the preparation of international standards. The objective of ISO is to facilitate the international exchange of goods and services through standardization and to develop mutual cooperation in the sphere of intellectual, scientific, technological and economic activity.

Organization and Scope. Iso is a decentralized organization based in Geneva. As of 1979, it was composed of the national standards institutions from 86 countries. A member body of ISO is the national body "most representative of standardization in its country." Thus, only one such body for each country is accepted for membership in ISO. More than 70 percent of the ISO member bodies are governmental institutions or organizations incorporated by public law, and most of the remainder have close links to the government, with the notable exception of the United States of America.

ISO's scope is broad, and it covers both technical and non-technical standards. It is not, however, active in the electrotechnical field which is the responsibility of the International Electrotechnical Commission (IEC).

ISO is administered by a president, a vice president, a treasurer, a secretary-general, and a council (its "Board of Directors"). The ISO Council has established a number of committees, including:

* The Commission of European Communities (CEC) is the executive arm of the European Economic Community, commonly referred to as the Common Market. 


\begin{tabular}{|c|c|}
\hline EXCO & - Executive Committee \\
\hline PLACO & - Planning Committee \\
\hline CERTICO & - Committee on Certification \\
\hline COPOLCO & - Consumer Policy Committee \\
\hline DEVCO & - Development Committee \\
\hline INFCO & $\begin{array}{l}\text { - Standing Committee for the Study of Scientific and } \\
\text { Technical Information on Standardization }\end{array}$ \\
\hline REMCO & - Committee on Reference Materials \\
\hline STACO & $\begin{array}{l}\text { - Standing Committee for the Study of Principles of } \\
\text { Standardization }\end{array}$ \\
\hline ISCA & $\begin{array}{l}\text { - International Standards Steering Committee for } \\
\text { Consumer Affairs }\end{array}$ \\
\hline
\end{tabular}

In order to better assess the needs for international standards in a particular field, ISO may create technical divisions (TD). At present, there are four technical divisions as follows:
TD 1 Mechanical Engineering
TD 2 Agriculture
TD 3 Building
TD 4 Distribution of Goods

Technical Committees. ISO's technical work is carried out through technical committees (TC) set up by the Iso Council, which also determines the scope of the committee. Within this scope, the committee determines its own program of work.

The technical committee may, in turn, create subcommittees (SC) and working groups (WG). Each technical committee and subcommittee has a secretariat, assigned to an ISO member body, and for each working group, a convenor is appointed by the parent committee. At the end of 1977, there were 154 technical committees, 585 subcommittees and 1140 working groups. By early 1979, the number of technical committees had risen to 157 .

Any member body has the right to be represented on any technical committee. Member bodies which actively participate are designated as P-members (participating) of that committee. Member bodies wishing only to be kept informed of the work of a technical committee or subcommittee are registered as 0-members (observers). The bulk of the work is carried out by correspondence. Each year, 10,000 working documents are evaluated. Meetings are convened when justified. In 1977, there were 617 Iso meetings held in 40 countries, representing almost 1500 working sessions.

ISO official languages are English, French and Russian. All working sessions are carried out in English and French.

International Standards. By the end of 1978, ISO had published 3750 international standards. Adoption of these by member countries is optional. ISO standards are available in English and French. Russian versions of ISO standards are issued at the discretion of the Soviet member body. 
AFNOR Participation. AFNOR is one of a handful of permanent members of the ISO Council and participates actively in all ISO Councll committees and activities.

Similarly, AFNOR is a member of practically every ISO technical committee and most subcommittees. The July 1979 particlpation statistics published by ISO show France as a "P" (particlpating) member 1 n all but three technical committees (TC 50 - Lac; TC 169 - Fishmeal; TC 174 - Jewelry) -- a record unmatched by any other country. The keen interest shown by France by being a voting member of so many committees is a strong 1ndication of the importance which France and AFNOR accord to International standardization work. Furthermore, the fact that French is an offlcial language in ISO encourages France's 1nvolvement in international standardization activities.

The number of secretariats held is another indication of the desire to participate and exercise a strong influence in ISO work. More than 20 percent of all ISO technical secretariats are in AFNOR's hands. For comparison purposes, distribution of secretarlats among major countries is shown in Table A.

Table A

Distribution of ISO Secretariats in 1979

\begin{tabular}{lrrrrr} 
& Total & France & UK & Germany & USA \\
\hline \multirow{2}{*}{ Technical Committees } & 157 & 31 & 24 & 21 & 14 \\
Subcomittees & 590 & 140 & 79 & 90 & 66 \\
Other groups & 1066 & 199 & 226 & 194 & 130 \\
\cline { 2 - 6 } & 1813 & 370 & 329 & 305 & 210
\end{tabular}

Even though member bodies have no obligation to adopt ISO standards, of the 501 ISO standards published in 1977, 90 percent were voluntarily incorporated, adopted or reproduced 1n AFNOR standards; 65 percent of the 90 percent were not modified.

Although bare statistics do not tell the whole story, there is no doubt that they show significant French interest in ISO work.

AFNOR Role. In al1 international work, AFNOR follows 1 ts usual practices for assuring participation by all interested groups and developing a coherent national position. For all ISO (and CEN) work, there is a parallel standardization committee in France under AFNOR auspices. These committees may be distinct from similar committees working on national French standards. More commonly, the same committee fulfills both functions, and meetings may be devoted to either national or international work, or to both. Usually a meeting is held to prepare for every international meeting in which France participates, and other meetings are 
held as needed for such things as voting on a draft. During committee meetings, the French position on issues to be discussed is agreed upon. To defend this position at ISO (and CEN) meetings, the committee appoints a delegation to represent it. Where travel is required, participants pay for their own expenses, as AFNOR has no travel funds for this purpose.

In recent years, the tendency towards adopting standards published by ISO as French standards has increased markedly. A very sizable portion of AFNOR's budget is spent on ISO and CEN activities, and it is generally felt that duplication of effort should be avoided.

\section{European Standardization}

CEN Background. The European Committee for Standardization (CEN**) was founded in Paris in 1961 as the "European Standards Coordinating Committee", a successor to a Common Market and European Free Trade Association committee set up in 1957. The present title of the group was adopted in 1971, when the purpose of the committee was redefined from a limited role of coordination and harmonization to a broader standards development role.

CEN Purpose. CEN aims to promote standardization at the European level in order to facilitate the exchange of goods and services by eliminating obstacles caused by technical requirements. To this end, CEN publishes European standards***. CEN also encourages the implementation of ISO standards, and it attempts to limit the scope of its work to subjects of special interest to its members which are not covered by ISO. Occasionally, CEN reluctantly duplicates ISO work if there is a particular regulatory need or trade interest.

Organization and Scope. CEN members are the standards organizations of Austria, Belgium, Denmark, Finland, France, West Germany, Ireland, Italy, Netherlands, Norway, Portugal, Spain, Sweden, United Kingdom, Switzerland, and, since early 1979, Greece. CEN is a decentralized organization based in Brussels. CEN has about 60 technical commitees (TC), with relatively limited scopes. Consequently subdivisions are not common. Official languages in CEN are English, French and German.

European Standards. By 1977, CEN had issued 48 standards of which 15 were approved in 1977. In 1978, 8 European standards were issued raising the total to 56. Official versions of these standards in English, French and German are on file in the Central Secretariat's offices in Brussels,

* This includes personnel, travel for AFNOR staff, hosting international meetings (meeting room, interpreters, etc).

** CEN stands for "Comité Éuropéen de Normalisation."

*** European standards are not to be confused with the "Euronormes" issued by the Commission of European Communities. These standards deal exclusively with steel products, and AFNOR actively participates in their development. 
but CEN does not publish European standards. Each country that has approved a European standard publishes it in its own language(s).

The development of CEN standards is extremely long and difficult because

the status of these documents is very special. Contrary to Iso where adoption is voluntary, a CEN member body who votes positively on a European draft standard is obliged to make, within six months, that exact text its national standard, and to withdraw any contradicting documents. Thus, European standards are published as, for example, French, British, Dutch or Finnish standards. Obtalning a consensus under such conditions requires great effort.

Cooperation With CEC. The European Committee for Standardization (CEN) works in close cooperation with the Commission of European Communities (CEC), but it is not a part of this organization, nor does it have any legal ties to the CEC. CEN's relationship to the CEC is one of cooperation in areas of mutual interest. Their relationship is similar to that existing between ISO and the United Nations Economic Commission for Europe*.

Not all members of the European Committee for Standardization (CEN) are countries belonging to the European Community, and not all CEN activity is related to Community needs.

The European Community includes nine countries: Belgium, Denmark, France, West Germany, Ireland, Italy, Luxembourg, the Netherlands, and the United Kingdom. CEN has sixteen member bodies, eight of which are not Community countries. These are: Austria, Finland, Greece, Norway, Portugal, Spain, Sweden and Switzerland. Luxembourg is not a CEN member. Any CEN member body may participate in the work of any CEN technical committee.

When the Commission of European Communities (CEC) decides to harmonize regulations in some particular sector, it may ask CEN to prepare a standard. No commitment of acceptance is given, nor does this request imply assurance that the European standard will be incorporated in CEC regulations. Such a request to develop a standard must be accepted by all CEN members. During committee work, however, an awkward situation may develop because there may be non-Community countries participating in the development of a standard that might eventually become a part of CEC regulations. Such situations increase the difficulties of approving drafts, because, while no CEN member body is obliged to participate in committee work, voting is compulsory.

AFNOR Participation and Role. France was instrumental in the creation of CEN and its involvement in CEN work is very intense. In 1977, AFNOR held 37 percent of all CEN secretariats and had adopted a majority of CEN

* For a specific example of the cooperative agreements between ISO and UN/ECE, see NBS Technical Note 976 "International Trends and Developments of Importance to the Metrication Plans of the US Construction Community." 
standards*. Many of the rules that govern committee work in ISO are used in CEN. AFNOR follows its usual practices, as described previously for ISO work, for channeling French participation in CEN.

\section{Future AFNOR Participation}

International standardization activities have increased at a very rapid rate in the last five to six years, and this trend will probably continue for years to come. AFNOR's commitment to the success of international standardization is seated in the deep conviction of the need for a technically rational basis on which to build and improve upon the worldwide exchange of goods and services. Increasing numbers of countries share this belief, and are participating more vigorously in standardization activities. France's long experience in the international field will hopefully help foster more effective international cooperation.

* When France does not approve a CEN standard it is not obliged to publish it. However, since AFNOR is responsible for the French language version and CEN does not publish standards, AFNOR issues European Standards not approved by France as information leaflets. 


\section{ENGLISH AND FRENCH TERMS}

An attempt has been made not to use French terms in the text. The translations are the author's and are not necessarily generally recognized terms. The exact French expressions are listed below opposite the English terms used in this report, which are in alphabetical order.

\section{English}

AFNOR (French Association for Standardization)

Agency of Consumer Affairs

Board of Directors (AFNOR) Bylaws (NF Mark)

Central Commission for Markets Central Laboratory for Bridges and Roads

Commission to Give Technical Opinions

Commissioner for Standardization Controller/Auditor

Counc1l of Ministers

Directing Committee (NF Mark)

Experimental standard

Field offices (AFNOR)

Fiscal Tax

French Association for Informative Labeling

General Assembly

General Director

Group for the Coordination of

Technical Texts

Implementation Decree

Information Leaflet

Inquiry directed to Ministries

Journal of Standardization

Ministry of Industry

Ministry of Equipment

Monthly Bulletin of French

Standardization

NF Mark

National Committee on Consumption

\section{FRENCH}

Association Française de Normalisation

Secrétariat d'État à la Consommation

Consell d'Administration

Règlement Particulier de 1a Marque NF

Commission Centrale des Marchés (CCM)

Laboratoire Centrale des Ponts et Chaussées (LCPC)

Commission chargée de formuler des avis techniques sur des procedés, matériaux, éléments ou équipments utilisés dans la construction (ATec)

Commissaire à la Normalisation

Controleur d'État

Consell des ministres

Comité de Direction de la Marque NF

Norme Experimentale

Délégations régionales

Taxe Parafiscale

Association Française pour

1 'Etiquetage d'Information (AFEI)

Assemblée Générale

Directeur Général

Groupe pour la coordination des textes

techniques

Décret d'application

Feuille de documentation or

Fascicule de documentation

Enquête Ministerielle

Courrier de la Normalisation

Ministère du Development Indus-

triel et Scientifique

Ministère de $1^{\prime}$ Equipement et du Logement

Bulletin Mensuel de la Normalisation Française (BMNF)

Marque NF

Comité National de la Consommation ( $\mathrm{CNC}$ ) 


\author{
National Institute on Consumption \\ Official Daily Journal \\ Permanent Commission for \\ Standardization \\ Permanent Groups for the Study of \\ Markets \\ Public Inquiry \\ Public Interest (AFNOR) \\ Ratified Standard \\ Registered Standard \\ Special Committee (NF Mark) \\ Specialized Groups (ATec) \\ Stamping Committee (NF Mark) \\ Standardization Bureaus \\ Standardization Committee \\ Technical Opinion
}

Institut National de la Consommation (INC)

Journal officiel (JO)

Commission Permanente de Standardisation

Groupes Permanents d'Etude des

Marchés (GPEM)

Enquête Publique (EP)

Reconnue d'utilité publique

Norme Homologuée

Norme Enregistrée

Comité Particulier de la Marque NF

Groupes Specialisés (ATec)

Comité d'Estampillage de la Marque NF Bureaux de Normalisation (BN)

Commission de Normalisation

Avis Techniques (ATec) 


\section{BUILDING STANDARDS}

\section{$\underline{\text { Standards }}$}

In France, building standards are developed under a special organization that does not fit elther of the two usual methods of standards development (i.e., the AFNOR committee method or Standardization Bureau method).

In the late 1950s, a variety of organizations concerned with building construction and standards agreed on some baslc procedures for developing building standards and other related documents. They formed a "Group for the Coordination of Technical Texts" informally designated as Group DTU*, which currently includes the following fourteen organizations:

- Association Française de Normalisation, (AFNOR)

- Centre Scientifique et Technique du Bâtiment, CSTB

- Fédération Nationale du Bâtiment, also known as UTI - Union Technique Interprofessionnelle ${ }^{+}$

- Centre Technique du Bois, $\mathrm{CTB}^{+}$

- Union Nationale des Syndicats Français d'Architectes (UNSFA) ${ }^{+}$

- Union Nationale Interprofessionnelle des Matériaux de Construction et Produits de Carriēres, UNICEM

- Fédération de Fabricants de Tuiles et Briques de France, (FFTB)

- Centre Expérimental de Recherches et d'Études du Bâtiment et des Travaux Publics, CEBTP

- Centre Technique Industriel de la Construction Métallique, (CTICM) ${ }^{+}$

- Groupement des APAVE

- Bureau Securitas ${ }^{++}$

- Bureau Veritas ${ }^{++}$

- Société de Contrôle Technique et d'Expertise de la Construction, SOCOTEC ${ }^{++}$

- Contrôle et Prevention, $\mathrm{CEP}^{++}$

* DTU stands for "Documents Techniques Unifiés," meaning "Unified Technica 1 Documents."

+ Standardization Bureau

H Private Inspection Organization 
The Group DTU acts as the General Committee for Standardization for building related issues. Its secretariat is held by CSTB.

The principal functions of the Group DTU include developing annual programs with long-range and short-range goals, deciding the work to be accomplished and distributing the various tasks, assessing progress on standards development, monitoring the activities of committees, and giving administrative and procedural approvals for processing drafts.

Development of a Standard

To understand how this complex system works, the development of a standard for clay bricks from inception to publication is illustrated. The annual program calls for a standard method for testing clay bricks to be published in three years. Most certainly this was included in the program at the request of the Federation of Tile and Brick Manufacturers (FTTB) which has a technical center available for testing and research. When FTTB is ready to commence work, the Group DTU will appoint both a "writer" ("rédacteur") and a "manager" ("animateur") for the specific draft to be developed. The appointment will be made at one of its regular bi-monthly meetings. While a formal decision must be made, obviously FTTB will be appointed the "writer". The "manager" may be FTTB, FTTB aided by some other organization such as CSTB or AFNOR, or AFNOR alone. The "manager" sets up a committee, calls meetings, distributes documents, keeps minutes of meetings, and redrafts documents. These committees have no specific bylaws, but they usually follow AFNOR practices. AFNOR assigns a reference number to the future standard.

The Group DTU is kept informed of progress and is alerted of any major problems in case rescheduling becomes necessary. When the committee feels the draft is adequate, the Group DTU is notified. At the next regular Group DTU meeting, the draft is approved for submittal to AFNOR for public comment. This approval is procedural, as the technical content of the draft is approved by the committee.

Following its customary procedures, AFNOR distributes the draft standard to a list of interested parties -- including committee members -- and prepares the press releases. All comments are sent to AFNOR. If a meeting is needed to resolve comments, AFNOR organizes the meeting. When the draft is in its final form, the Group DTU gives final approval for publication, which is handled by AFNOR.

Standards Types

Building standards in France cover a wide range of subjects and usually relate to terminology and vocabulary, definitions, methods of test, and product specifications. Installation guidelines and minimum system design standards are not published as standards. These types of documents, called "cahiers de charges DTU", are developed and published by CSTB. They are, however, under the jurisdiction of the Group DTU. The 
"writer" and "manager" of these "cahiers de charges"* is usually CSTB. Other organizations may be appointed co-writers. The Group DTU monitors the progress of the "cahiers de charges" and gives procedural approval for publication. Technical approval is given by the committee set up to study the draft proposal. The composition of these committees is similar to that of standard-writing committees. Since these documents are not standards, they do not have to comply with the requirements Imposed on standards and are thus not submitted to public inquiry nor to the ministries for comment and approval.

"Cahiers de charges" are extensively used in France and enjoy a very high reputation. They are not, however, consensus documents as they do not undergo public inquiry and comment. However, "cahiers de charges" are endorsed by the Central Commission for Markets (CCM)** and become an integral part of that commission's standards for construction. (These "standards" are called Cahiers des Clauses Techniques Générales destiné aux Marchés Publics de Bâtiment, translated as General Technical Specifications for Building Construction by Public Contracting.)

"Cahiers de charges" are considered authoritive guidelines, showing one adequate way of accomplishing a job. Standards and "cahiers de charges" are complementary documents and are usually used jointly. For example, a "cahier de charges" on joinery would specify how to install wood windows, wood doors and other wood components such as closets, kitchen cabinets, partitions, etc. Where appropriate, reference is made to product and material standards. In turn, the product standard on wood windows, for example, may indicate the appropriate "cahier de charges" to consult.

The dichotomy between product and material standards on one hand, and installation guidelines and systems design on the other, is peculiar to the building industry. In most other flelds, AFNOR standards address all aspects of a technology.

In addition to "cahiers de charges," the Group DTU establishes design rules ("règles de calcul") for reinforced concrete, steel, wind and snow loads, etc.

Another trait peculiar to French bullding standards is that both standards and "cahiers de charges" include only products, methods and systems considered "traditional". Performance history must be known through long field experience before a product or system is considered by the Group DTU. For example, wood and metal windows are standardized with methods of tests, performance criteria, and construction characteristics, "cahiers de charges" give installation guidelines for wood

* "Cahier de charges" may be loosely translated as "specifications." They include technical and administrative clauses of the type usually agreed on at the awarding of a contract. 
joinery and metal joinery. However, plastic windows are not yet considered traditional and fall under other procedures for new products.

\section{New Products}

New products, as well as not-so-new but non-traditional products and methods, may be subjected to a procedure known as an "Avis Technique," (ATec) which means "technical opinion."

Only products and methods too new to be standardized (or whose use is innovative) may be subjected to an ATec procedure. Technical opinions (Avis Techniques, or ATecs) are issued as information documents to give all interested parties authoritative opinion on the forseeable behavior of products and systems, but they do not imply governmental or CSTB approva1. Conformance with them is not mandatory, although new products and methods which do not have a favorable Avis Technique may sometimes encounter difficulty in being widely accepted.

The "Commission to Give Technical Opinions"* was created by a government decree in December 1969 to replace the earlier "Agrément" system.

The Commission's members are identified in Article 7 of the 1969 decree. AFNOR is a permanent member of the Commission. The Commission forms "specialized groups"** to examine requests for technical opinion, appointing a chairman and establishing the composition of each group. The groups may also call on outside experts for consultation and active participation in meetings. The CSTB (one of the organizations mentioned earlier) registers, publishes and keeps records of all ATec activity, and acts as Secretariat to the Commission and its groups.

ATecs must be requested and must be made for a specific product, as manufactured by a specific company in known factories and as intended for use in defined conditions. A trade association, for example, may not request an ATec for "plastic windows". Manufacturer X may, however, request an $A T e c$ for plastic windows $A, B$ and $C$, intended for residential use in all climates, and manufactured in two localities. In the event of a favorable ATec, a statement of particular conditions of use and/or of installation may be included in the ATec. An ATec is valid for a limited period of time -- anywhere from 1 to 5 years. ATecs are published and copies may be obtained from CSTB by anyone.

Requests are presented to appropriate "specialized groups" while CSTB carries out all necessary testing. Testing procedures may be based on standardized methods modified as needed, or new procedures may be established. The specialized group makes a decision based on test results and visits to sites where the product has been previously used.

* Hereinafter referred to as the Commission.

** In 1978, some sixteen "specialized groups" were functioning. 
Costs of testing and administrative expenses are paid by the petitioner to CSTB, according to a fee schedule approved by the Board of Directors of CSTB with the consent of the Commission. Participation on the committee work of the groups is voluntary.

The relationship between standardization activities and ATec activities is spelled out in the Commission's by-laws, (approved by the Ministry of Equipment (Public Works) in 1971), as a mutually cooperative and supportive effort. These two activities address different issues but are complementary. When products reach a point when they are considered traditional, the standardization process takes over.

\section{Civil Code}

France's building regulation enforcement system is'quite different from the U.S. system. Most jurisdictions have building regulations limited to zoning, architectural coherence, historic preservation and related subjects. National legislation usually addresses urban development, and attempts, among other things, to remedy the acute housing shortage. Some specific national legislation deals with fire safety, elevators and thermal insulation.

Under articles 1792 and 2270 of the Civil Code (involving civil and penal liability), builders are accountable for ten years for structural integgrity and for two years for other work.

Under the Civil Code, non-conformity with rules and regulations is punishable only when the non-conformity causes harm. Systematic inspection of constructions is rare, but a building permit may be refused for non-compliance to rules and regulations.

Instead of systematic inspection by building officials, as in the U.S., there may be inspection of certain buildings by private organizations for insurance purposes.

Insurance policles may cover one or all parties involved in the construction, as well as the construction itself. Private, independent inspection groups (such as Veritas, Securitas, Socotec and others, members of the Group DTU) are extensively involved in field inspections. Certain types of insurance coverages, in particular for large works or risky constructions, require private inspection groups to be on site to verify compliance with rules, regulations, standards, cahiers de charges, design rules, etc.

A recent law passed in January 1978 concerning responsibility and insurance in bullding construction made the manufacturer and the bullder jointly responsible for the building construction and made insurance mandatory. 
Building regulation is a vast and complex subject. A comprehensive treatment is not within the scope of this appendix and would require further research. The intention of the preceding brief description is to give an outline of the system and to underline the very basic differences that exist between French and U.S. practices in this field. 


\section{BIBLIOGRAPHY}

Bulletin Mensuel de la Normalisation Française

(Monthly Bulletin of French Standardization), AFNOR*, April 1978.

Catalogue de Normes Frangaises

(Annual Catalog), AFNOR, 1978.

Courrier de la Normalisation

(Journal of Standardization), AFNOR,

No. 256 - July/August 1977 (General Assembly 1977),

No. 259 - January/Fe bruary 1978 ,

No. 261 - May/June 1978 (1977 AFNOR Annual Report).

Iso Memento

ISO**, 1978 and 1979

ISO Annual Report

ISO, 1977 and 1978.

Reprint of decrees and general ordinances concerning ATec, CSTB***.

Reprint of laws, decrees and ordinances concerning standardization from 1918 to 1975, AFNOR.

Statuts, Règlement Intérieur

(Statutes and Internal Rules), AFNOR, 1977.

* AFNOR: Tour Europe, Cedex 7, 92080 Paris la Defense, France.

** ISO: 1 rue de Varembé, 1211 Geneva 20, Switzerland.

*** Centre Scientifique et Technique du Bâtiment: 4 Avenue du Recteur Poincaré, 75016 Paris, France. 


\section{association française de normalisation}

TOUR EUROPE CEDEX 792080 PARIS LA DÉFENSE

acces : LA DEFENSE $2 \cdot$ COROLLES

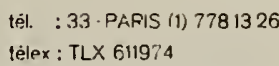

afner

vos rèlèrences.

nos rẹte:ences: $D G E / C E$ no 1 fo4h

otjpt: $\underline{\text { Rapport de Melle MARTINEZ }}$

pieces jointes-anriaxes 1 note

1 rapport
Mademoiselle Joan A. KOENIG

U.S Département of Commerce

National Bureau of Standards

Washington, D.C. 20234

(U.S.A.)
TOUP EUROPE

le $1: 3$ novembre 1979

\section{Mademoiselle,}

Je vous retourne le projet de rapport réalisé par Melle MARTINEZ sur la normalisation en France, après vérification des différents services de l'AFNOR.

Ce rapport est complet et présente parfaitement la situation française. Toutefois il a été relevé quelques inexactitudes qui ont été corrigées au crayon sur le texte, ou qui sont portées sur la 'note ci-jointe.

Je vous serais reconnaissant de me.faire parvenir un exemplaire du rapport définitif, une fois qu'il sera publié.

Avec mes remerciements, je vous prie d'agréer, Mademoiselle, l'expression de mes sentiments les plus distingués.

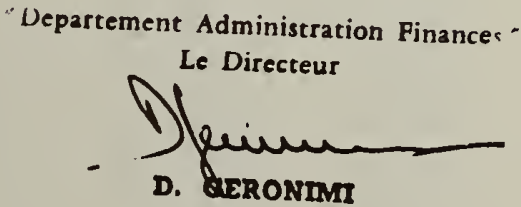




\section{UNOFFICIAL TRANSLATION OF \\ AFNOR LETTER}

Subject: Miss Martinez's report

$\begin{array}{ll}\text { Attached: } & 1 \text { note } \\ & 1 \text { report }\end{array}$

Ma dame,

I am returning the draft report prepared by Miss Martinez on standardization in France, after consulting with several groups in AFNOR.

This report is complete and presents perfectly well the French situation. However, some inaccuracies have been noted and have been corrected in pencil in the report or are explained in the attached note.

I would appreciate a copy of the final report, once it is published.

With my thanks,

sincerely,

D. Geronimi, Director

Administration and Finances Department 


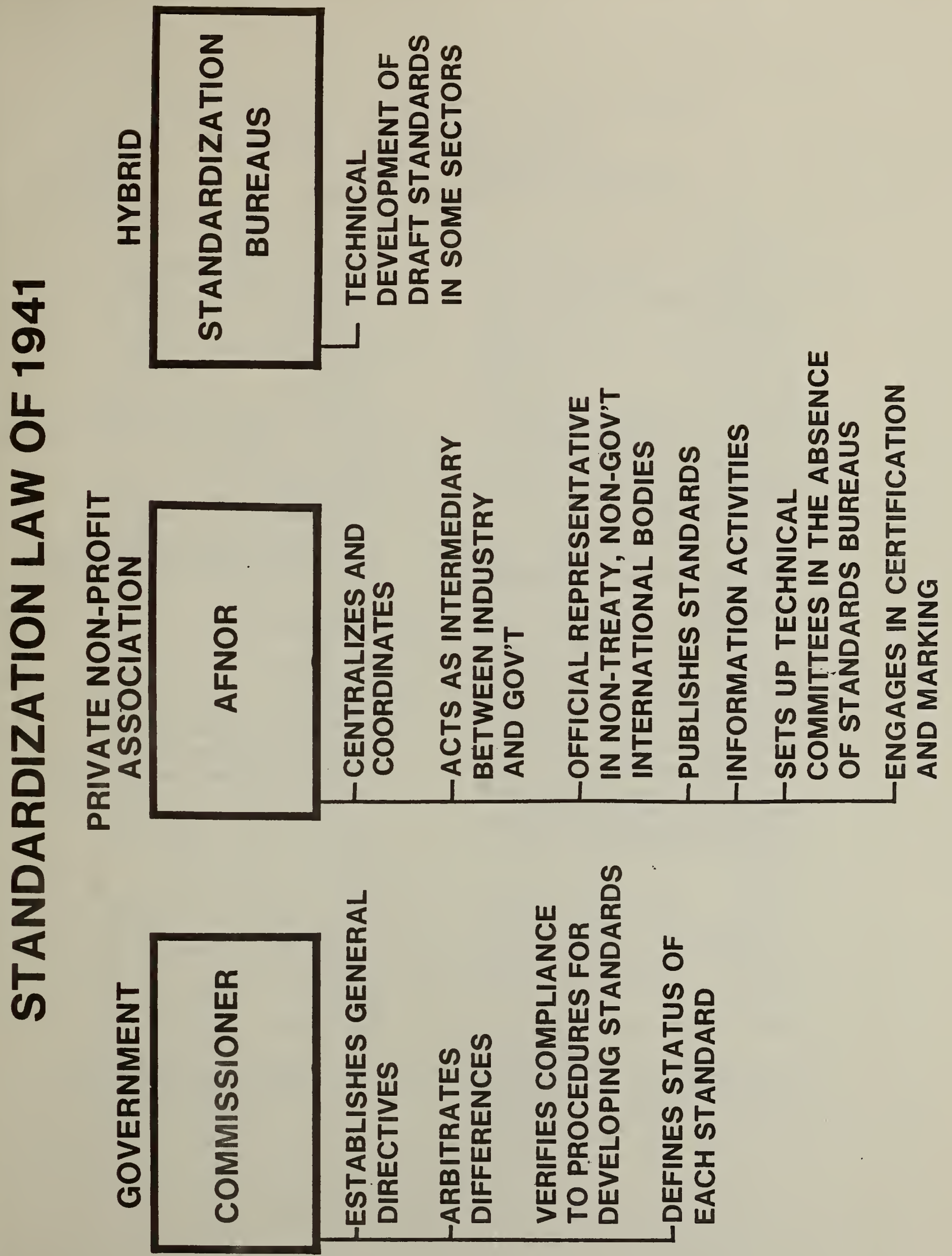


Figure 2

List of Standardization Bureaus*

by Subject Areas Covered

French

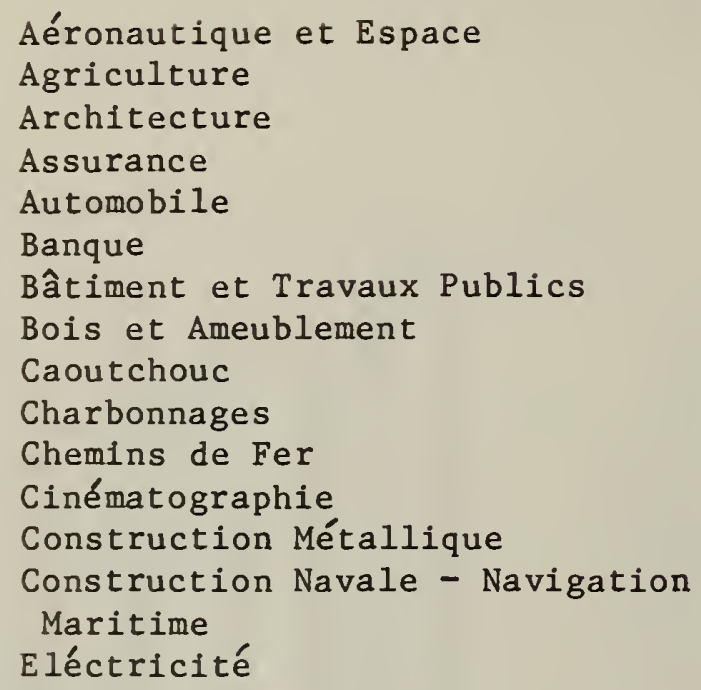

\section{English Translation}

Aircraft and Space Vehicles Agriculture Architecture Insurance Automobile Banking

Building Construction and Public Works Wood and Furniture

Rubber

Coal Mining.

Railroads

Cinematography

Metal Constructions (Structures)

Shipbuilding - Sea Navigation

\section{Electricity}

Bottling

Cast Iron

Gas

Clothing

Watches and Clocks

Computer Technology

Hydraulic Binders (cement, plaster, etc.)

Building Materials

\section{Plastics}

Mechanica 1 Industries

Metals

Paper

Petroleum

Photography

Steel

Welding

Textiles

Stee 1 Tubes

* For the exact titles and addresses of the Bureaus, see AFNOR Annual Catalog. 
List of Technical Areas Covered by French Standards

(as given by AFNOR's Annual Catalog)

French

\section{Catalog Classification}

A Métallurgie

B Carriēres-Céramique-VerreRefractaires-Bois-Liege

C Eléctricité

D Economie Domestique-Ameublement

E Mécanique

F Chemins de fer

G Textiles et Cuirs

H Emballage-Manutention-Transport

$\mathrm{J}$ Construction et Industries Navales

$\mathrm{K}$ Banque - Valeurs Mobilieres Assurance

L Aerronautique et Espace

$M$ Combustibles

P Bâtiment et Travaux Publics

Q Papiers et Cartons - Technologie Graphique

R Automobile - Motocyclce - Cycle

$S$ Industries Diverses (Optique Photographie - Cinématographie Acoustique - Eclairage Jeux et Sports - Matériel de Lutte Contre l'Incendie Protection et Securité Horlogerie - Medicine Chirurgie)

T Industries Chimiques

U Matières et objets utilisés en Agriculture

$V$ Produits de l'Agriculture, de la Pêche et des Industries

Alimenarires

$X$ Normes Fondamentales-Normes Générales

Z Administration - Commerce Documentation-Traitement de 1' Information
English Translation

\author{
Metallurgy \\ Quarry Materials - Ceramics - Glass - \\ Refractories - Wood - Cork \\ Electricity \\ Household goods - Furniture \\ Mechanics \\ Railroads \\ Textiles and Leathers \\ Packaging - Mechanical Handling - \\ Transportation
}

Shipbuilding and Naval Industries

Banking - Real Estate - Insurance

Aeronautics and Space Technology

Fuels

Building Construction and Public Works

Paper and Boards - Graphic Technology

Automobile - Motorcycles - Bicycles

Miscellaneous Industries (Optics -

Photography - Cinematography -

Acoustics -Lighting - Games

and Sports - Fire-fighting

equipment - Protection and

Safety- Horology (equipment for measuring time and time keeping keeping (clocks and watches)

- Medicine - Surgery)

Chemical Industries

Machinery and products used in Agriculture

Agriculture products, Fishing, and Food Industries

Fundamental Standards and General Standards

Management - Trade-Documentation

(Library Sciences)-Information

Processing (Computer Sciences and Technology) 


\section{TYPICAL COVER PAGE OF A FRENCH STANDARD}

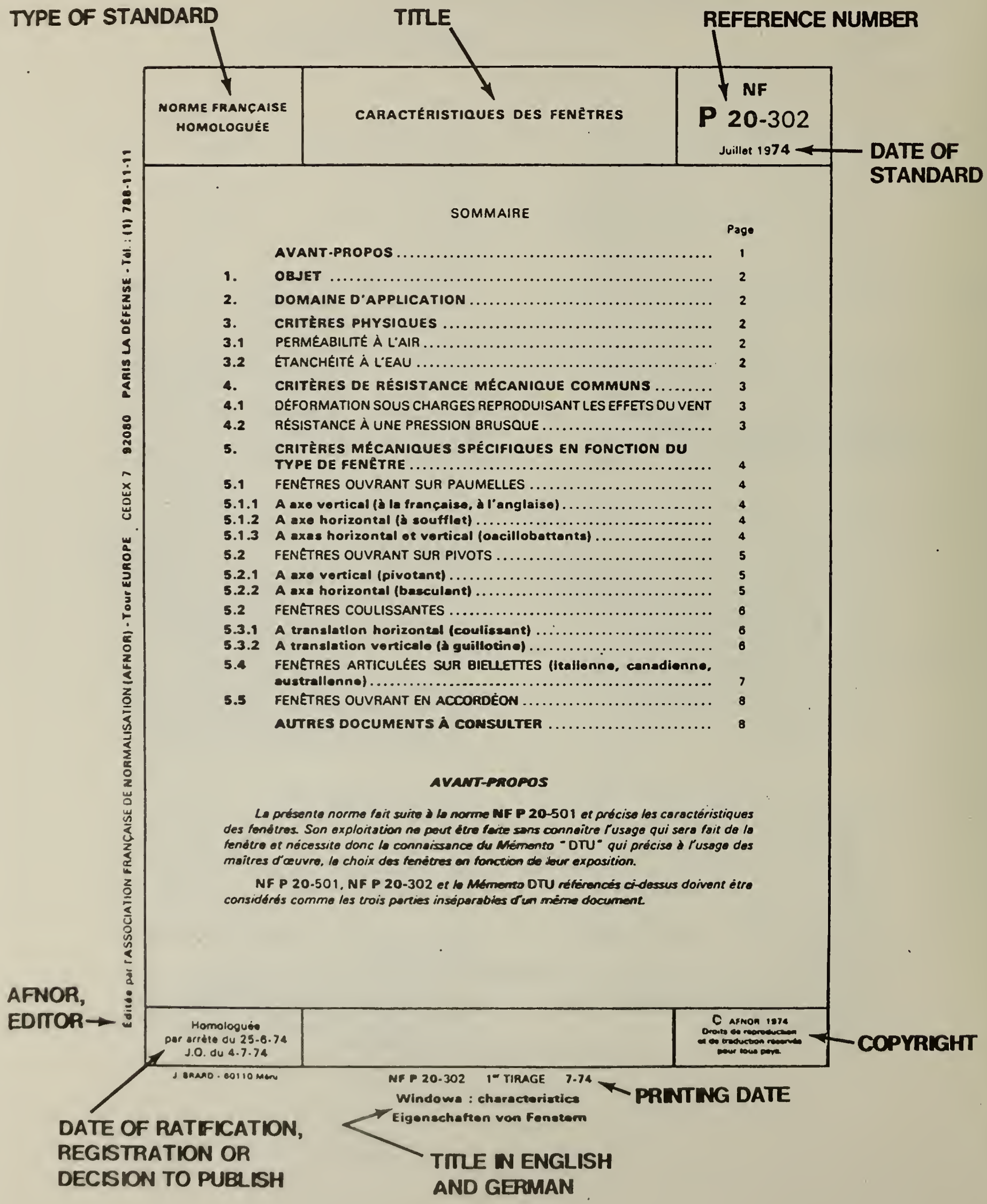




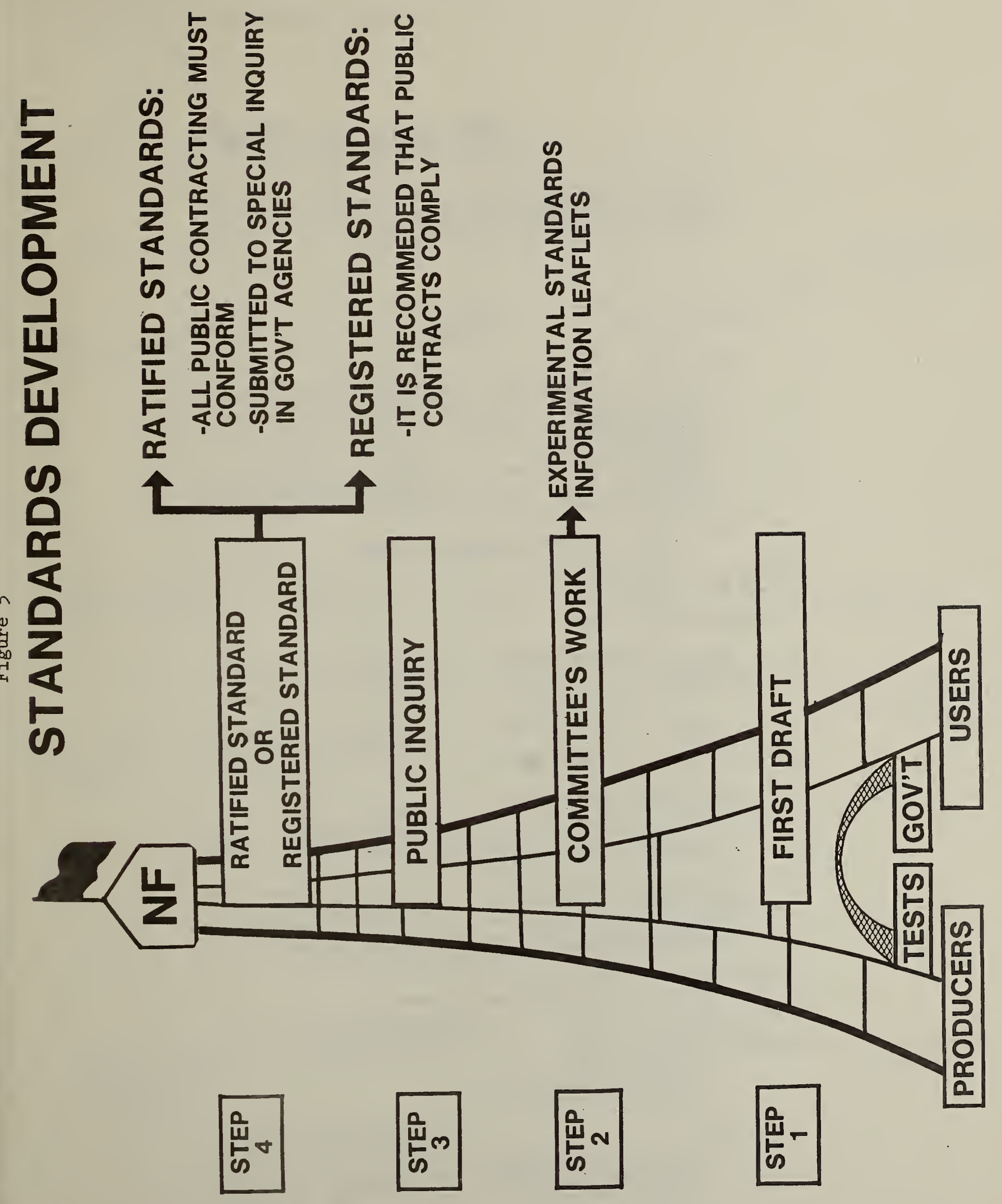




\section{travaux en cours}

Oans celte rubrique sont mentıonnes certains documents non desınes a être communıques au public En eltet, representant une etape transitoire de travaux de commission en cours. Is n'ont en general de signitication qu'a la lumiere dautres
documents anterieurs ou de complements en preparation Le lirage en est. pour celte raison. Iimite en tonction des eltectits de la commission interessee

Seuls les projets arrives au stade de l'enquete publique sont diffuses sans eucune restricllon pendant la durée de l'enquète coci independamment, bien entendu. de la dittusion ulterieure des normes definilives

\section{ADHÉSIFS}

X Reunion

26 avril : AFNOR - Commiosion - Collea ot collagas .

Etabtissement du programme de trevail de le commission et de ses groupes de travail n" 1 iे 4 .

Mise eu point de la réponse trançaise sur les avant-projets iso

DP $6354 / D A D$ 1 Adriésits - Vocabulare

DP 194 /DAD.11 " Liste des termes equivaients - Terminologie des adhésits.

Avis de la commission sur les projels de normes sulvants en cours d'enquête publique :
- Pr B 51-338 - Contreptequé à plis - Methodes d'esseis des plens de college.

plequé à plis - Definitions at qualens de college.

Avls de le commission sur le document . Exirait diun document relatif aux stratiliés décoralifs .

Echenge de vues sur les lieisons de le commission evec daautres instances normelisetrices (AECMA. comite Cechniaue ISO/TC 136 . Tubes, reccords ot robinetterie en metieres plastiques pour le iransport des tluides $\cdot$ ).

\section{AERONAUTIQUE ET ESPACE}

\section{New Standards \\ Issued \\ 2 aEUNIONS}

3 eyrll : Bureeu de normelisation de l'eb́roneutique et de ".opece (BNAE). Groupe de trevell GT 44/1. Tachym

Meetings Held By

Standardization

Bureaus

Examen du projet concernant les tachymetres.

3 avrh : IMAE - Groupe de travell GT 44/2 - Coplours a imputsione.

Sulte de l mude des cheines alimeniées per une source exterioure

3 evrll : Abroupattete - Groupe de trevall GT 06 - Donsler 3 ovrll : Acroes
Indusiriol.

Examen des reponses reçues à la sulle de l'enquéle sur lo projet de recommendation générale RG. Aero 00006 de colte recommandation.

4 -vill : BNAE - Commission de brenche - AGrodynes al organes.- Groupe ad hoc - Segments d'errill.

Resultets des essals entrepris sur les segments d'orrét.

Examen du projet de norme Pr L 23-211. Segments d'arret a montage exial. Specification technique.

Revision des normes NF $L$ 23-201, NF L 23-202 et NF $L$ 23-203 sur les segments d'arrét

- Exemen de l'utlité d'une tolarence de battement pour le fond de gorge.

- Examen des temperetures meximales d'utllisation.

5 avrll : BNAE - Groupe de trevall GT 80 - Rlvelege ."

Révision de la recommendetion de lebrication RF Aéro 95011 "Rivetage à l'elde de rivels spéclaux "SL - en 30 NCD16 et en T-AGV - Exéculion et contróle .

6 ot 7 ovril : BNAE.

Constitution de la delegation lrençelse et fixation de to position frençeise sur les principeux points Inscrits a AECMA $6 C^{3}$. Mécenlque.

13 avrll : Serrlea lechnique abroneutique (STA) - Group do Iravell GT 40 - Tuyeutertas - Reccords at jotnts .

Examen du compte rendu de réunlon ISO/TC 20/SC 10 Exare du comple rendu do rounton isorice $2015 \mathrm{~s}$ io N 262 ot des princlpeux points interessalt.

\section{ÉCONOMIE DOMESTIQUE}

\section{Ongoing Public Inquiries}

ENOUETES PUQLIOUES

11. 3516 (Lave-maIns). D. 223

$n=3525$ (Climatiseurs). D 223

n. 3530 (Equipement de cheutlage des machines laver le linge), D. 223

n* 3535 (Tuyeux llexibles pour apperells à usege domestique). P 223

र

AEUNTON

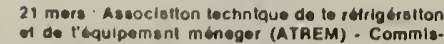

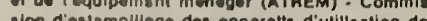
meetlaue doe gez. Eatumpltte NF.GAZ.

Maintien du droit au port de testampille eccordo sans ousers a 70 apposterls $(24$ tobles de trevalt. 14 lebles de d) NORMES NOUVELLES

Voir peges roses (D)

Iravell combinees - 6 cuisiniores combinbes - 14 cuiletnieres - 2 redialeurs - 10 cheudieres à deux services) Examen et reconnaissence de la contormile eux normes d"un prototype

Examen de 19 appereils de serie 16 edmissions doni 5 avec observations ( 4 tables de travall - 4 culsiniéres. 2 redieteurs . 2 chaudieres - 4 chaudieres a deux sorvices).

Examon des resultets d'essois effectubs eu titre du controle sur 7 appsreils 2 loni l'objet d'observations. une suspension de ficence est prononcee. 


\section{SÉCURITÉ ET PROTECTION}

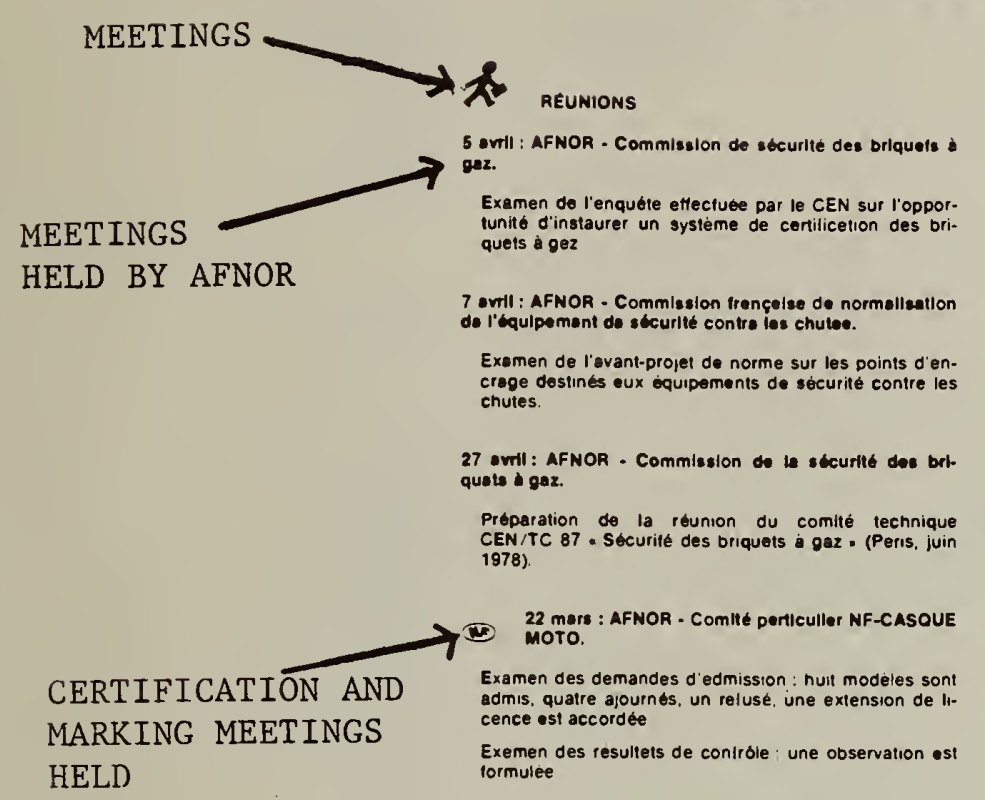

SOUS-COMITE TECHNIOUE ISO/TC 94/SC I Securlti Indlviduelie. Vetements ot equlpements de profection - Casques de protection. profection - Casques de protection -"
(Sererterlet : BSI - Royeume-UnI)

- du 4 au 6 avril 1978, à Peris.

- Participeient à le reunion des dèlégues de 10 peys dont le Frence

Principales questions examintes

- Méthode de chute de le tausse tét

- Mise au point el modifications

groupe de travail ISO/TC 94 SC

1/GT 3 . Fousses teres :

- Choc tatéral : essai dynamique du systeme de rélen-

GROUPE DE TRAVAIL ISO/TC $94 / S C$ 1/GT 1 - Slgnallsation des cosques:
(Secrétarlat : AFNOR - France)

- te 3 evril 1978, à Montlihóry.

Participerent à le réunion des délégues de 3 pays, dont la France.

Principale question examinee :

Mise au point d'un texte $d$ avant-projet en fonction des observations formulees.

\section{SOUDAGE}

\section{NEW STANDARDS ISSUED \\ NORMES NOUVELLES \\ Voir pages roses (A) \\ 12 aEUNIONS}

13 evrll : AFNOR - Commission trançalee de le soudure (essels el contróle des soudures).

Preparation de la réunion du sous-comile technique ISO/TC 44/SC 5 . Soudure. Essais de contróle des soudure - (Genes, mai 1978). Delinition du point de

ourll: AFNOR - Commisision trencelse to to souduro (meitriel de soudage aux gar).

Préparation de la réunion du sous-comilé technique ISO/TC 44/SC 8 . Materiel de soudage aux gaz = (Berlin. mai 1978) - Delinition du point de vue du comite membre trençais. Habilitation de le délégation frençasse à cette reunion.

SOUS-COMITE TECHNIOUE ISO/TC 44/SC 8 - Soudure - Materiel de soudage par réalstance.

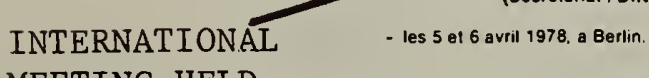

- Participaient à la réunion des délegués de 4 peys, dont la France (plus 1 pays par procuration).

Principales questions examinies

- Rapport du secréteriat.

Coordination des travaux du sous-comité technique ISO. TC 44; SC 6 el du comite CEI, CE 26.

- Revision de la recommandation ISO, R 865 concer nent les reinures dens les plateaux pour les machines de soudage par bossages.

- Avant-projet concernant les trenstormeteurs de soudage par resistance, transformateurs incorpores.

- Conducteurs souples secondeires pour les machines à souder, relroidis à l'air.

- Cylindres pour machines a souder multipoints.

- Symboles graphiques sur le matériel de soudage par résistance,

- Programme des traveux fulurs
INTERNATIONAL MEETING HELD IN PARIS

\section{MEETING HELD $A B R O A D$}




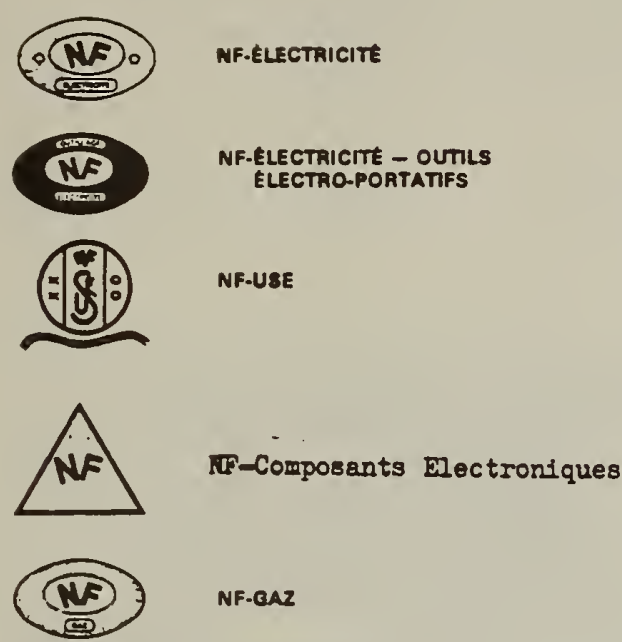

NF-OAZ
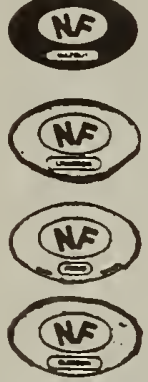

NF-CUISSON
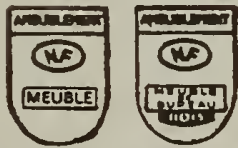

NF.MEUBLE

NF-MEUBLE DE BUREAU
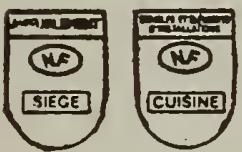

NF.SIEGE

NF.CUISINE

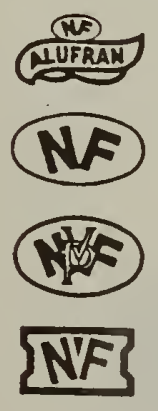

NF-ALUFRAN

NF-CRISTAL

NF-VP

NF.BLOCS EN BETON

NF.BETONS PRETS A L'EMPLOI

PREPARES EN USINE

NF-BOISSEAUX DE TERAE CUITE

NF.briQues CREUSES dE TERRE CUITE

NF-TUILES EN EETON

NF-COMPLEMENT D'ETANCHETTE

(NF)

NF-ELEMENTS DE MOSAIOUE DE

PATE DE VERAE

NF-REACTION AU FEU

NF-ROBINETTERIE

NF-RE SERVOIRS NON ENTERRES EN MATIERES PLASTIOUES

NF.STOCKAGE PETROLIER

NF.UMITEURS DE REMPUSSAGE

NS NF.ENTREVOUS EN BETON

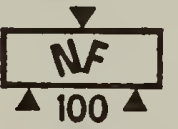

(IV)

BETON

\section{NF-PLAQUES ONDULEES EN}

AMIANTE-CIMENT

NF-PLAOUES ONDULEES EN POLYESTER

NF.TUYAUX EN AMIANTE-CIMENT

NF-ELEMENTS DE CANALISATIONS EN GRES

NF.CARREAUX OE MOSAlQUE DE MARBRE

NF-CTB PORTES PLANES

NF.CTB PARQUETS MOSAIQUE

NF-CTB nf-ctB lames a parquet en

CHENE MASSIF

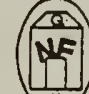

NF-ARTICLES DE QUINCAILLERIE

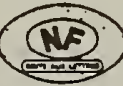

NF-BOITES AUX LETTRES

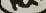

सiin

NF
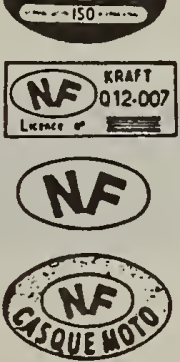

NF.MIH

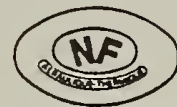

NF.AERAULIQUE ET THERMIOUE

NF.CONTENEURS

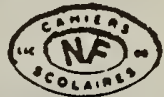

NF-KRAFT

NF-CAHIERS SCOLAIRES

NF-FILTRES DE PROTECTION

OCULAIRE

NF-MIRES ET MICROMIRES

NF.BUTYROMETRES A LAIT

NF.CASQUE MOTO 
Figure 8

\section{REPRINT FROM THE OFFICIAL DAILY JOURNAL MAKING A STANDARD COMPULSORY (AS PUBLISHED IN A BMNF)}

\section{MISE EN APPLICATION OBLIGATOIRE DE NORMES FRANÇAISES ('J.O., du 4 avril 1978, p. 1496)}

\begin{abstract}
Le ministre délegué à l'óconomie at aux finances, le $\mathrm{mt}$ nistra de l'agnculture of la ministra de l'industrie. du commerce et de l'artisanat.

Vu la loi du 15 fevrier 1991 relativa à torganisation da la production, du transport at de la distribution \&u gaz:

Vu la loı du $24 \mathrm{mal} 1941$ ralative à la normalisation:

Vu le decrat ou 24 mai 1941 fixant le statut de la norma-

Vu le decret du 23 mal 1962 fixant les régles techniques at de securité applicables aux installations de gaz

Vu l'arrete du 15 avril 1942 portant statut de la marque nationale de contormite aux normes

Vu las arrêtes du ministre de lindustrie ou 21 tévriar 1966 of du 24 feverier 1976 portant modification at codifica. uon des régles de contormité des appareils et matériels à $g a z$ aux normes trançalses les concernant.

Vu tarrété du 2 aoút 1977 relattl aux règlas techniques at de securité applicables aux installations de gaz combustible et d hydrocarbures liquefies situees à linterour des bátıments d'habitation ou de leurs dependances

Vu larvicie 23 dis du code des douanes

Sur proposition du commissaire a la normalisation.

$$
\text { Arrètent }
$$
\end{abstract}

Ant 1" - Dans un délal de daux mois a compter de la dats de publication ou present arrété. Il est interdit d'imconar. pour la mise a la consommation, des matérieis et apperails domesiques a gaz qui na satisiont pas aux conditions imposees par larrete susvisa du 21 tevirier 1966. tol qu'il a ele moditie par les arretes subsequants, a notumment par l'arrété du 24 tevrier 1976, ou aux condisitinse

Art. 2- La charga da la prauve de la contormité aux dispostions de farticle $1 *$ incombe aux fabricants ou aux importateurs

Art 3 - Cette preuve resulte

1 Pour les maleriels et appareils domestiques utilisant los combustibias gazaux qui sont titulaires de la marque nationale de coniormite aux normos NF-GAZ. de la pré

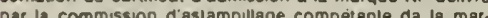
Que NF-GAZ ansi qua da prege competanie da la mar-

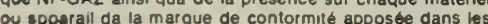
condition fixtes par le ibglemant particuliar correspondent

2 Pour ves materials at apparells domestiquas utilisen les combusibles gszaux qut ne sont as atelares de le marqua nationale da conformute sux normas NF-GAZ mais

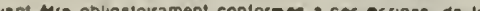
prenter de de pre

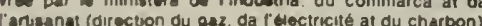

Cefta attastation certifia que contróle techniqua dont les modalités sont définies aux articles 5 at 7 dudit arrété a ble subi avec succes. le maintien da certa attestation etant subordonne aux résult
par les servicas compétents.

3. Pour les matérials at appareils domestiques utlisant les combustiblas gazeux qui ne sont pas couverts par des normes obligatoires mass qui sont soumis aux dispositions de f'arréta susvisé du 2 aoút 1977. d'une antastation d'agrement délivrée par la ministera de l'industre. du commarca et de l'artisanat (direction du gaz. de l'electr. cité et du charbon) en application des prescriptions de l'artıcle $4\left(1^{\circ}\right)$ de cet arrèté.

Art. 4 - Saut dans le cas où un certificat d'admission a la marque NF-GAZ peut étra produit et oú la marque da les imporlateurs de materiels et d'appareils domastiques utilisant les combustiblas gazeux sont tenus de presenter. selon le cas. à l'appui de la déclaration en douane pour la mise à la consommation, l'artestation da contrôle technique ou l'attestation d agremant prevue aux paragraphes 2 et 3 de l'article 3 ci-dessus

Art 5. Si une directive adoptée par le conseil des communautes européennes comprend das dispositions incompatibes avec celles du present arrete ca darnier sere moditié en conséquence

Art. 6 - Le diractaur génèral des douanas at droits indirects du ministere de l'economie et des finances, le diraclaur de la qualite (service de la repression des iraudes at du contrōle de la qualıté) du ministèra da l'agricultura. le commissarre a la normalisation, le directeur du gaz. de relectricita et du charbon, la directaur des Industries mólallurgiques, mecaniques, lia directaur des industecteur das Carisants du minisque de lindusthe. du commerca al de lexecution ou present arrete qui cera publie au Jouma

Fait à Paris, le 29 mars 1978

Le ministra da lindustria, du commerca at da leartisana.

Pour le ministra at par délegation.

Le commissaire é la normatisation.

FRANÇOIS BARET

La ministra délégué dè f'economia ef aux finances. Pour la ministra at par délégation :

Le diractaur général das douanes ef droils indirects.

$$
G \text { VIDAL }
$$

La ministra da lagriculfura. Pour le minisira el par délégation

La diraclaur da la quallte. e mathieu

SH'étude est déjà faile, pourquoi la refaire ? Achetez la norme! 
TRANSLATION OF THE REPRINT FROM THE OFFICIAL DAILY JOURNAL MAKING A STANDARD COMPULSORY (AS PUBLISHED IN BMNF)*

\section{Rendering Mandatory French Standards (Journal Official dated April 4, 1978, page 1496)}

The Minister of Economy and Finance; the Minister of Agriculture; the Minister of Industry, Commerce and Manual Trades.

In view of the February 15, 1941 law concerning the production, transportation and distribution of gas.

In view of the May 24, 1941 law concerning standardization.

In view of the May 24, 1941 decree establishing the statutes of standardization.

In view of the May 23, 1962 decree establishing the technical and safety rules applicable to installations of combustible gas.

In view of the April 15, 1942 ordinance establishing the statutes on the national mark of conformity to standards.

In view of the February 21, 1966 and February 24, 1976 ordinances of the Minister of Industry modifying and codifying for gas appliances and equipment the rules of conformity to the relevant French standards.

In view of the August 2, 1977 ordinance concerning the technical and safety rules applicable to installations of combustible gas and liquid hydrocarbons located inside buildings used for habitation and their dependencies.

In view of article 23 bis of the customs Code.

On the proposal of the Commissioner for Standardization. Dec ide:

Article 1. Within two months of the publication of the present ordinance, it is forbidden to import for the consumer market gas equipment and appliances that do not satisfy the conditions set forth by the aforementioned ordinance of February 21, 1966, as modified by subsequent ordinances and in particular by the February 24, 1976 ordinance; or the conditions set forth by article 4 of the aforementioned ordinance of August 2, 1977 .

Article 2. The responsibility for proving conformity to the provisions of article 1 falls on manufacturers or importers.

* This translation is for the reader's information only. It is not meant to be an official translation. 
Article 3. This proof results from:

1. For household equipment and appliances which use combustible gases, holding the national NF-GAZ mark of conformity to standards, the presentation of a certificate of admission to the NF mark by the competent NF-GAZ stamping committee, as well as the presence on each piece of equipment or appliance of the mark of conformity affixed under the conditions specified by the corresponding NF by-laws.

2. For household equipment and appliances, which use combustible gases and which do not hold the national NF-GAZ mark of conformity to standards but that under the terms of the aforementioned ordinance of February 21, 1965 shall be obligatorily in conformity to those standards, the presentation of a document verifying technical control issued by the Ministry of Industry, Commerce and Manual Trades (Department of Gas, Electricity and Coal). This verification certifies that technical control, the methods for which are defined in article 5 and 7 of that ordinance, has been successfully achieved. The upholding of such a verification is subordinate to the results of the control procedures carried out by the competent office.

3. For household equipment and appliances using combustible gases that are not covered by mandatory standards, but that are subject to the provisions of the aforementioned ordinance of August 2, 1977, of a document verifying approval issued by the Ministry of Industry, Commerce and Manual Trades (Department of Gas, Electricity and Coal) under the provisions of article $4(1)$ of that ordinance.

Article 4. Except in the cases where a certificate of admission to the NF-GAZ mark is presented or where each piece of equipment or appliance has affixed to it the mark of conformity, the importers of household equipment and appliances using combustible gases must present, depending on the case, in support of the customs declaration for placement in the consumer market, the document verifying technical control or the document verifying approval as specified in paragraphs 2 and 3 of article 3 above.

Article 5. If a directive adopted by the Council of European Communities includes provisions incompatible with those of the present ordinance, the former will be modified.

Article 5. The General Director of Customs and Indirect Taxes of the Ministry of Economy and Finance; the Department for Quality (Office of Repression of Fraud and Quality Control) of the Ministry of Agriculture; the Commissioner for Standardization; and the Director of Gas, Electricity and Coal, 
the Director of Metallurgical, Mechanical and Electrical

Industries and the Director of Carburants of the Ministry of Industry, Commerce, and Manual Trades are charged, for their respective areas, with the execution of the present ordinance that will be published in the Official Daily Journal of the French Republic.

In Paris, March 29, 1978:

sas

The Minister of Industry, Commerce, and Manual Trades. For the minister and by delegation: the Commissioner for Standardization, FRANCOIS BARET.

The Minister of Economy and Finances. For the min ister and by delegation: The General Director of Customs and Indirect Taxes, G. VIDAL.

The Minister of Agriculture. For the minister and by delegation: The Director for Quality, E. MATHIEU. 
The Office of Standards Information, Analysis, and Development (OSIAD) is part of the NBS National Engineering Laboratory's Office of Engineering Standards. OSIAD has established a Standards Impact Analysis (SIA) project to provide NBS decision-makers and others with information that will help them better understand the national and international standards systems and the economic, social, and other impacts of standards. It is hoped that this information will increase the effectiveness of NBS's participation in voluntary standards work and will contribute to the development of more rational and cost effective standards.

Functions of the SIA program include:

- Identifying needs for research: 1. on the impacts of standards; and 2 . on standards systems and how they operate, and making these known to the academic, economic and standards communities;

- Conducting or contracting for needed research of specific interest to NBS programs; and

- Maintaining close liaison with NBS and outside groups involved in standards impact or system assessment and developing a collection of studies in this area.

Some areas in which SIA has sponsored research are:

Regulatory use of standards

Standards systems in Canada, the UK, West Germany, and Denmark Economic principles applied to standards-writing

Economics of certification.

For information on SIA studies, contact Joan Koenig (telephone: 301-921-2092; address: Tech Bl62, National Bureau of Standards, Washington, D.C. 20234). 
NBS.114A IREV. 9.78 )

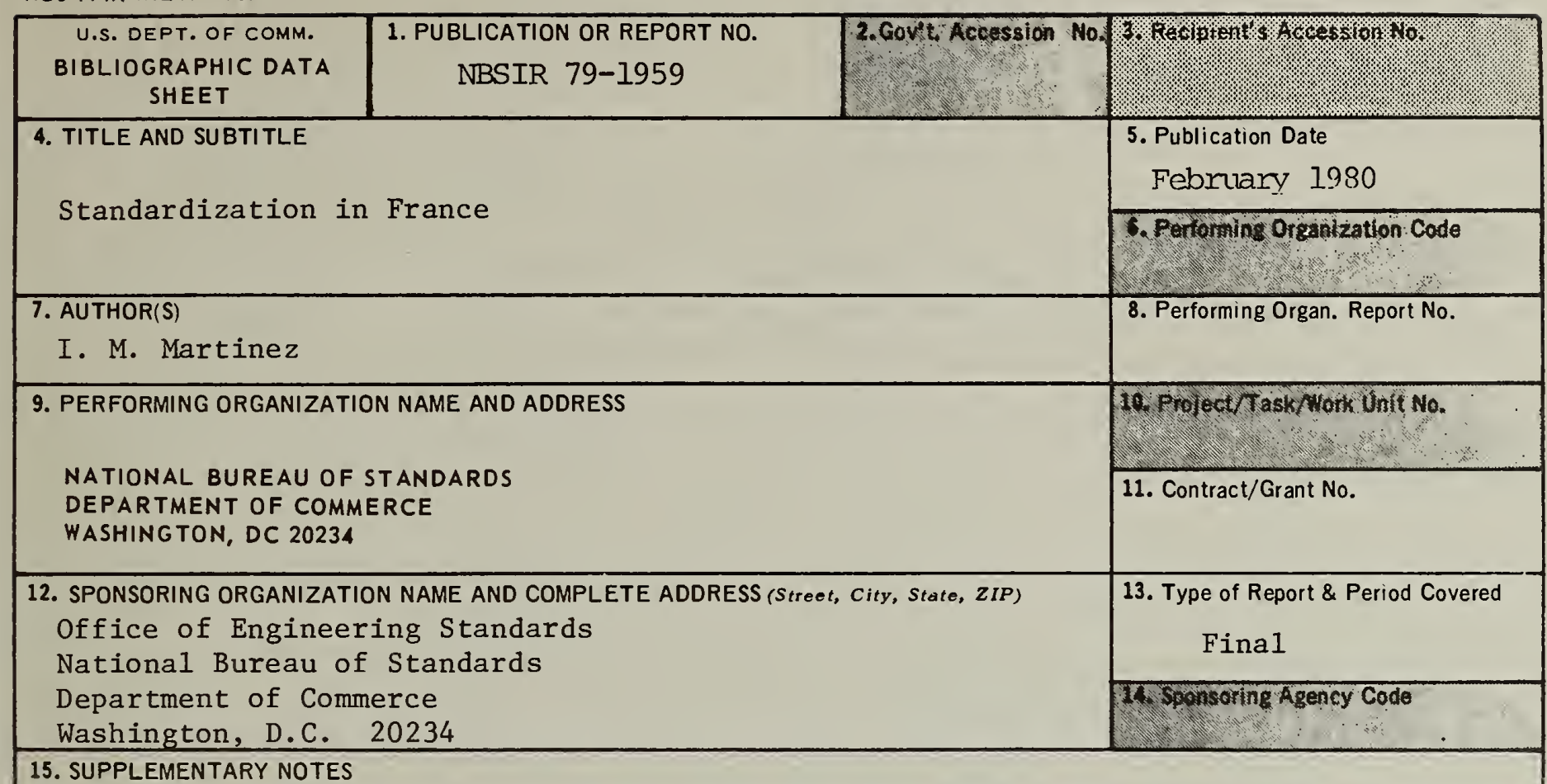

15. SUPPLEMENTARY NOTES

Document describes a computer program; SF-185, FIPS Software Summary, is attached.

16. ABSTRACT (A 200-word or less factual summary of most significant information. If document includes a significant bibliography or literature survey, mention it here.)

This report provides an overview of the voluntary standards system in France. The author, a former employee of AFNOR - the official French standardization organization, calls on her firsthand experience to discuss the following aspects of the French standard system: (1) Orpanization, (2) French Standards, (3) Standards Development, (4) Certification, (5) Government Use of Standards, (6) The Role of Consumers and Labor in Standardization, and (7) France's Participation in International Standards Activities.

17. KEY WORDS (six to twelve entries; alphabetical order; capitalize only the first letter of the first key word unless a proper name; separated by semicolons)

AFNOR; antitrust; certification; product; France; French standards system; government policy; Standards systems;

18. AVAILABILITY

For Official Distribution. Do Itot Release to NTIS

Order From Sup. of Doc., U.S. Government Printing Office, Washington, DC 20402, SD Stock No. SNO03-003-

[X] Order From National Technical Information Service (NTIS), Springfield, VA. 22161

\begin{tabular}{|l|c|}
\hline $\begin{array}{l}\text { 19. SECURITY CLASS } \\
\text { (THIS REPORT) } \\
\text { UNCLASSIFIED }\end{array}$ & $\begin{array}{c}\text { 21. NO. OF } \\
\text { PRINTED PAGES }\end{array}$ \\
\hline $\begin{array}{l}\text { 20. SECURITY CLASS } \\
\text { (THIS PAGE) }\end{array}$ & $\begin{array}{l}22 . \text { Price } \\
\text { UNCLASSIFIED }\end{array}$ \\
\hline 7.00 \\
\hline
\end{tabular}




